\title{
$1 \quad$ Can calcium aluminates activate ternesite hydration?
}

2

$6 \quad *$ corresponding author: blancomt@ietcc.csic.es

7 Abstract

9 Aluminium hydroxide $\left(\mathrm{AH}_{3}\right)$ has recently been shown to be able to activate hydration in 10 ternesite, a phase found in some calcium sulfoaluminate (CSA) cements.

11 This study explored the capacity of a number of calcium aluminates $\left(\mathrm{C}_{3} \mathrm{~A}, \mathrm{C}_{12} \mathrm{~A}_{7}, \mathrm{CA}\right.$

12 and $\mathrm{C}_{4} \mathrm{~A}_{3} \overline{\mathrm{S}}$ ) to activate ternesite hydraulic reactivity. After laboratory synthesis, the

13 aluminates were blended with ternesite at a ratio of 1:2 and their hydration was

14 monitored with isothermal conduction calorimetry for 7 days at $25^{\circ} \mathrm{C}$. The resulting

15 pastes were analysed with XRD, FTIR and DTA. The presence of ternesite in the pastes

16 altered the aluminate heat flow curves, shortening the induction period and bringing the reaction peak forward, an indication of hastened hydration. Ternesite also altered the reaction products, which included calcium monosulfoaluminate hydrate and strätlingite.

\section{Keywords:}

Ternesite, Calcium Aluminates, Hydration Products, Hydration Heat

\section{Introduction}


27 The mass production of portland cement (OPC) entails the consumption of vast amounts of raw materials and accounts for $4 \%$ to $6 \%$ of worldwide anthropogenic $\mathrm{CO}_{2}$ emissions (0.8-0.9 t $\mathrm{CO}_{2} / \mathrm{t}$ clinker) [1].

The cement industry is currently seeking to develop less energy-intensive, lower

Greenhouse gases (GHG) emission cements. Calcium sulfoaluminate (CSA) cements, one of the most promising alternatives, are characterised by lower energy costs (at $1250{ }^{\circ} \mathrm{C}$, the clinkering temperature is $200{ }^{\circ} \mathrm{C}$ lower than in OPC clinker) and GHG.

34 These products emit from $25 \%$ to $40 \%$ less $\mathrm{CO}_{2}$ during manufacture than OPC, depending on the composition [2]. Whilst not presently used for structural purposes due to the lack of the necessary regulation, they are commercialised as components for special mortars and concretes (such as repair or self-levelling concrete, sealing mortar or shotcrete).

The composition of the clinker in these cements may differ, although all lie in the $\mathrm{CaO}$ $\mathrm{Al}_{2} \mathrm{O}_{3}-\mathrm{SiO}_{2}-\mathrm{Fe}_{2} \mathrm{O}_{3}-\mathrm{CaSO}_{4}$ system and have lower calcium and silicon and higher aluminate and sulfate phase contents than portland cements. The minerals present in the clinker include $\mathrm{C}_{4} \mathrm{~A}_{3} \overline{\mathrm{S}}, \mathrm{C}_{2} \mathrm{~S}, \mathrm{C}_{12} \mathrm{~A}_{7}, \mathrm{CA}, \mathrm{Cs}$ and $\mathrm{C}_{4} \mathrm{AF}^{*}$, although the aluminates predominate $[3,4]$.

Ternesite, $\mathrm{C}_{5} \mathrm{~S}_{2} \overline{\mathrm{S}}$, which also lies within this system, is a phase compatible with ye'elemite $\left(\mathrm{C}_{4} \mathrm{~A}_{3} \overline{\mathrm{S}}\right)$ and $\mathrm{C}_{2} \mathrm{~S}$. It is found primarily in the crust covering the areas of portland cement kilns where the temperature is no higher than $1250^{\circ} \mathrm{C}$ and as a minority component in some CSA cements $[5,6,10]$. A calcium sulfosilicate, ternesite is formed in the reaction between anhydrite and belite. Bullerjahn et al. $[6,7]$ proposed a two-stage method for ternesite formation, in which clinker is synthesised at a temperature of $1250{ }^{\circ} \mathrm{C}$ and then cooled by gradually ramping the temperature down to 
$51800{ }^{\circ} \mathrm{C}$. Further to recent thermodynamic predictions and empirical observation, if

52 atmosphere (partial pressure of $\mathrm{SO}_{2}$ and $\mathrm{O}_{2}$ ) and temperature are controlled, belite- and

53 ternesite-high sulfoaluminate clinkers can be readily produced in a single-stage process

54 at temperatures of over $1200{ }^{\circ} \mathrm{C}[8]$.

55 Although ternesite has traditionally been regarded as hydraulically inactive and of no

56 technological interest [9], recent studies have shown that it is activated by amorphous

$57 \mathrm{AH}_{3}$. It hydrates, then, in their presence, yielding ettringite and C-S-H respectively the

58 main hydration products in CSA and portland cements and the phases to which they

59 owe their mechanical strength and durability. Strätlingite may also form with or instead

60 of C-S-H [11].

61 Solubility of amorphous aluminum hydroxide in water at $25^{\circ} \mathrm{C}$ is very low ([Al] $\approx$ $621,607 \times 10^{-7} \mathrm{M} / 1$ and $\mathrm{pH}$ 6,789; database used: concrete_3T_V07_02 and calculated with 63 Phreeqc), it depends on the $\mathrm{pH}$ of medium and it rises both when $\mathrm{pH}$ increases or 64 decreases from neutrality, being $\mathrm{Al}(\mathrm{OH})_{4}{ }^{-}$the only ionic specie present at $\mathrm{pH}$ higher 65 than $\approx 8,5$ [11]. Solubility of ternesite is not known, but it seems that its dissolution 66 produces hydrolysis and a $\mathrm{pH}$ near to 12 [12].

67

68 The solution in contact with ternesite and $\mathrm{AH}_{3}$, contains $\mathrm{Al}(\mathrm{OH})_{4}^{-}, \mathrm{Ca}^{2+}, \mathrm{SO}_{4}{ }^{2-}, \mathrm{SiO}_{3} \mathrm{H}^{-}$,

$69 \mathrm{OH}^{-}$ions that will react when the solubility products of ettringite or strätlingite or

70 calcium monosulfoaluminate hydrate or or C-S-H etc, are achieved; the precipitation of

71 the said phases will consume ions in solution stimulating then new ternesite

72 solubilisations.

73 Given the low water solubility of $\mathrm{AH}_{3}$, other, more soluble aluminates might be thought

74 to act as activators and stimulate ternesite hydration more efficiently. 
76 Such aluminates and ternesite might be the main phases in a future CSA cement with a

77 composition lying within the $\mathrm{CaO}-\mathrm{Al}_{2} \mathrm{O}_{3}-\mathrm{SiO}_{2}-\mathrm{Fe}_{2} \mathrm{O}_{3}-\mathrm{CaSO}_{4}$ system.

78 The purpose of this study is to explore the capacity of a series of calcium aluminates $\left(\mathrm{C}_{3} \mathrm{~A}, \mathrm{C}_{12} \mathrm{~A}_{7}, \mathrm{C}_{4} \mathrm{~A}_{3} \overline{\mathrm{S}}\right.$ and $\left.\mathrm{CA}\right)$ to activate ternesite hydration, establishing the reactions involved and identifying the reaction products.

81

82

\section{Experimental}

84

Ternesite $\left(\mathrm{C}_{5} \mathrm{~S}_{2} \overline{\mathrm{S}}\right)$, ye'elemite $\left(\mathrm{C}_{4} \mathrm{~A}_{3} \overline{\mathrm{S}}\right), \mathrm{C}_{3} \mathrm{~A}, \mathrm{C}_{12} \mathrm{~A}_{7}$ and $\mathrm{CA}$ were synthesised from stoichiometric blends of laboratory-grade $\mathrm{CaCO}_{3}, \mathrm{SiO}_{2}, \mathrm{Al}_{2} \mathrm{O}_{3}$ and gypsum

$87\left(\mathrm{CaSO}_{4} \cdot 2 \mathrm{H}_{2} \mathrm{O}\right)$. The samples were weighed, ground in a ceramic mortar, homogenised in an ethanol medium and dried at $100{ }^{\circ} \mathrm{C}$. A pressure of $300 \mathrm{kp} / \mathrm{cm}^{2}$ was applied to the powder obtained to prepare $2 \mathrm{~cm}$ diameter cylindrical pellets weighing approximately

$4 \mathrm{~g}$. The pellets were calcined at $1200{ }^{\circ} \mathrm{C}\left(\mathrm{C}_{5} \mathrm{~S}_{2} \overline{\mathrm{S}}\right), 1250{ }^{\circ} \mathrm{C}\left(\mathrm{C}_{4} \mathrm{~A}_{3} \overline{\mathrm{S}}\right), 1350{ }^{\circ} \mathrm{C}\left(\mathrm{C}_{12} \mathrm{~A}_{7}\right.$ and $\mathrm{CA})$ or $1400{ }^{\circ} \mathrm{C}\left(\mathrm{C}_{3} \mathrm{~A}\right)$ for $2 \mathrm{~h}$. They were subsequently ground, homogenised, dried and new pellets were prepared and calcined at the same temperatures, ternesite and ye'elemite for $6 \mathrm{~h}$ and the other calcium aluminates for $5 \mathrm{~h}$. This process was repeated through conclusion of the synthetic reactions.

Particle size distribution in the synthesised phases was determined and recorded on a Malvern Mastersizer S particle size analyser with $632.8 \mathrm{~nm}$ He-Ne laser optics after subjecting samples suspended in ethanol with 5 drops of dispersant (DOLAPIX CE64 1/100) to ultrasonic dispersion for $5 \mathrm{~min}$. The findings are given in Figure 1 and

99 Table 1. 
100 Phase purity was determined by applying Rietveld refinement to the X-ray diffraction

101 (XRD) patterns (Table 2).

102 Aluminates and ternesite blend hydration (aluminate:ternesite $=1: 2$ by mass) were

103 monitored for $7 \mathrm{~d}$ at $25^{\circ} \mathrm{C}$ on a Thermometric TAM Air isothermal conduction

104 calorimeter. Three g of sample were stirred manually with $2.1 \mathrm{~g}$ of water (liquid/solid

105 ratio $=0.7$ ) for 3 min prior to insertion in the calorimeter. Upon finalisation of the

106 calorimetric tests, the samples were submerged in acetone to detain hydration and

107 vacuum drying was used to remove water. The products were characterised with X-ray

108 diffraction (XRD), IR spectroscopy (FTIR) and differential thermal analysis-

109 thermogravimetry (DTA-TG).

110 The mineralogy of the synthetic phases and hydrated samples was determined on a

111 Bruker D8 Advance X-ray diffractometer, fitted with a high voltage, $3 \mathrm{~kW}$ generator

112 and a $1.54 \AA \mathrm{CuKa}$ anode X-ray tube operating at $40 \mathrm{kV}$ and $50 \mathrm{~mA}$. This instrument

113 was coupled to a Lynxeye detector with a $3 \mathrm{~mm}$ anti-scatter slit and a $0.5 \% \mathrm{Ni}$ K-beta

114 filter, with no monochromator.

$115 \mathrm{XRD}$ patterns of synthesized aluminates and ternesite were recorded at $5^{\circ}-70^{\circ} 2 \theta$

116 angles, with a step size of $0.01973^{\circ}$, and a $2 \mathrm{~s}$ step time. Rietveld quantitative analysis

117 [13] was conducted on the XRD findings using GSAS software [14].

118 XRD patterns were recorded for the ternesite-bearing hydrated aluminates, likewise at

$1195^{\circ}-70^{\circ} 2 \theta$ angles with a step size of $0.01973^{\circ}$, while varying the step time to $6 \mathrm{~s}-10 \mathrm{~s}$.

120 Corundum $\left(\mathrm{Al}_{2} \mathrm{O}_{3}\right)$ was added to these samples at a rate of $25 \%$ to quantify the

121 amorphous phase [15].

122 XRD scans were taken of the aluminate hydrated samples $5^{\circ}-60^{\circ} 2 \theta$ at a step size of

$123 \quad 0.019746^{\circ}$ and a $0.5 \mathrm{~s}$ step time. 
$124 \mathrm{C}_{12} \mathrm{~A}_{7}+$ ternesite hydration was also XRD-monitored for $20 \mathrm{~h}: 5^{\circ}-30^{\circ} 2 \theta$ angles, step

125 size $0.019746^{\circ}$ and step time $0.5 \mathrm{~s}$. Scans were recorded every 10 min during the first

$12610 \mathrm{~h}$, and every $30 \mathrm{~min}$ from the $11^{\text {th }}$ through the $20^{\text {th }}$ hours. The paste was introduced

127 in an air-tight sample holder to prevent carbonation and drying.

128 For FTIR analysis of the $7 \mathrm{~d}$ pastes, vacuum pressure of 10 atm was applied for 3 min to

129 pellets prepared with approximately $1 \mathrm{mg}$ of sample in $300 \mathrm{mg}$ of $\mathrm{KBr}$. FTIR scans

130 were performed at frequencies of $4000 \mathrm{~cm}^{-1}-400 \mathrm{~cm}^{-1}$ on a Thermo Scientific Nicolet

131600 FTIR spectrometer with a spectral resolution of $4 \mathrm{~cm}^{-1}$. The $\mathrm{CA}$ and $\mathrm{C}_{12} \mathrm{~A}_{7}$ pastes

132 were also scanned after heating to $188^{\circ} \mathrm{C}$ at $10{ }^{\circ} \mathrm{C} / \mathrm{min}$ in an $\mathrm{N}_{2}$ atmosphere.

133 Thermogravimetric (TG) and differential thermal (DTA) analyses were conducted on a

134 TA Instruments Q600 TGA-DCS-DTA analyser. The samples were heated from

135 ambient temperature to $1000{ }^{\circ} \mathrm{C}$ in a nitrogen atmosphere $(100 \mathrm{~mL} / \mathrm{min})$ at a rate of

$13610^{\circ} \mathrm{C} / \mathrm{min}$.

\section{3. Results}

\subsection{Isothermal conduction calorimetry}

143 The heat flow curve for ternesite alone contained only the first exothermal peak, which

144 after $1 \mathrm{~h}$ had declined to $31 \mu \mathrm{W} / \mathrm{g}$, given its scarce reactivity with water [6], the total

145 heat of this reaction was very low (Figure 2 and Table 3). During hydration at $25^{\circ} \mathrm{C}$, the

146 heat flow curves for both the synthesised aluminates $\left(\mathrm{C}_{3} \mathrm{~A}, \mathrm{C}_{12} \mathrm{~A}_{7}, \mathrm{CA}, \mathrm{C}_{4} \mathrm{~A}_{3} \overline{\mathrm{S}}\right)$ and their

147 blends with ternesite (Figure 3 and Table 3) showed an early exothermal reaction after

148 mixing followed by a decline in the heat production rate and, in the $\mathrm{C}_{12} \mathrm{~A}_{7}, \mathrm{CA}$ and 
$149 \mathrm{C}_{4} \mathrm{~A}_{3} \overline{\mathrm{S}}$ samples, a second exothermal reaction that appeared earlier in the presence of

150 ternesite.

151 The intensity of the initial exothermal signal in the $\mathrm{C}_{3} \mathrm{~A}$ heat flow curve tended

152 downward for the first $7.5 \mathrm{~h}(6.6 \mathrm{~mW} / \mathrm{g})$, steadied until $10 \mathrm{~h}$, continued downward until

$153 \mathrm{t}=24 \mathrm{~h}(0.75 \mathrm{~mW} / \mathrm{g})$ and then remained flat through the rest of the test. Gismera-Diez et

154 al. [16] reported the same pattern. In the presence of ternesite the decline was steeper

155 and uninterrupted through $13.5 \mathrm{~h}(0.08 \mathrm{~mW} / \mathrm{g})$, after which no thermal signals were

156 recorded.

157 The heat flow curves for pastes $\mathrm{C}_{12} \mathrm{~A}_{7}$ and $\mathrm{C}_{12} \mathrm{~A}_{7}+$ ternesite contained two exothermal

158 peaks following the very intense initial peak and an intermediate induction period. The

159 first appeared after $1 \mathrm{~h}$ in both whereas the second was recorded $2.5 \mathrm{~h}$ earlier in the

160 sample with than in the one without ternesite. A new, low intensity but long-lasting ( $9 \mathrm{~h}$

161 to $20 \mathrm{~h}$ ) exothermal signal appeared in the sample containing ternesite. Raab et al. [17]

162 regarded $\mathrm{C}_{2} \mathrm{AH}_{8}$ as the first product of $\mathrm{C}_{12} \mathrm{~A}_{7}$ hydration, giving rise to the first visible

163 peak on calorimetric graphs. The second peak would denote a further hydration

164 reaction.

165 Induction began very quickly on the CA and CA+ternesite paste flow curves, after

166 approximately $2 \mathrm{~h}$ (the second peak observed in the $\mathrm{C}_{12} \mathrm{~A}_{7}$ pastes was not found here),

167 and ended much earlier in the sample with ternesite $(2.5 \mathrm{~h}$ and $15 \mathrm{~h})$, whilst the highest

168 reaction peak for the blended sample was recorded at $4.5 \mathrm{~h}$, compared to $21 \mathrm{~h}$ for the

169 sample with CA only. In addition to the aforementioned signals, the curve for paste CA

170 showed a slight rise in heat flow between $11 \mathrm{~h}$ and $13 \mathrm{~h}(1 \mathrm{~mW} / \mathrm{g})$, while the slope on

171 the CA+ternesite curve changed twice on the descending leg of the second heat flow

172 peak, at around $11 \mathrm{~h}(1.8 \mathrm{~mW} / \mathrm{g})$ and $17 \mathrm{~h}(0.8 \mathrm{~mW} / \mathrm{g})$. 
174 Similar behaviour was observed for the paste $\mathrm{C}_{4} \mathrm{~A}_{3} \overline{\mathrm{S}}$ heat flow curves. The presence of

175 ternesite barely altered the beginning of the induction period $(1.5 \mathrm{~h})$ but changed the end

176 time: the second signal peaked at $4 \mathrm{~h}, 3 \mathrm{~h}$ earlier than in the unblended sulfoaluminate

177 paste. The $\mathrm{C}_{4} \mathrm{~A}_{3} \overline{\mathrm{S}}$ curve exhibited a slight rise in heat flow between $4 \mathrm{~h}(0.39 \mathrm{~mW} / \mathrm{g})$

178 and $6 \mathrm{~h}(2 \mathrm{~W} / \mathrm{g})$, in addition to the aforementioned signals. This pattern was also

179 observed by Sánchez-Herrero et al. [18], who reported a first peak at around $4 \mathrm{~h}$ and a

180 second and more intense peak at 6.5-7 h. The graph for the ternesite-bearing paste

181 contained a low intensity exothermal signal with a peak at $1 \mathrm{~h}$ after the very intense

182 initial dissolution peak, as well as a change in the slope on the descending leg of the

183 second heat flow peak at around $9.5 \mathrm{~h}$.

184 In the absence of ternesite, the total heat released by the $7 \mathrm{~d}, 25^{\circ} \mathrm{C}$ samples was as

185 follows: $\mathrm{C}_{3} \mathrm{~A}>\mathrm{CA} \approx \mathrm{C}_{12} \mathrm{~A}_{7}>\mathrm{C}_{4} \mathrm{~A}_{3} \overline{\mathrm{S}}$. In the presence of the said mineral, the order was

$186 \mathrm{CA}>\mathrm{C}_{12} \mathrm{~A}_{7}>\mathrm{C}_{3} \mathrm{~A}>\mathrm{C}_{4} \mathrm{~A}_{3} \overline{\mathrm{S}}$ (Figure 4 and Table 4). Although the samples containing

187 ternesite exhibited much lower heat of hydration than the unblended aluminate pastes,

188 the total heat per gramm of aluminate increases between 19 and $91 \%$.

189

190

191

192

$193 \mathrm{CA}, \mathrm{C}_{12} \mathrm{~A}_{7}$ and $\mathrm{C}_{3} \mathrm{~A}$ hydration yields $\mathrm{C}_{3} \mathrm{AH}_{6}$, the sole stable calcium aluminate hydrate

194 in the $\mathrm{CaO}-\mathrm{Al}_{2} \mathrm{O}_{3}-\mathrm{H}_{2} \mathrm{O}$ system, as well as a number of metastable phases $\left(\mathrm{CAH}_{10}\right.$,

$195 \mathrm{C}_{2} \mathrm{AH}_{8}, \mathrm{C}_{4} \mathrm{~A} \cdot \mathrm{xH}(\mathrm{x}=7,11,13$ or 19$), \mathrm{C}_{2} \mathrm{~A} \cdot \mathrm{xH}(\mathrm{x}=4,5,7.5$ or 8$\left.)\right)$ depending on the

\subsection{XRD study}$$
\text { temperature and composition of the aluminate hydrated. }
$$

The diffractograms for the $7 \mathrm{~d}\left(25^{\circ} \mathrm{C}\right) \mathrm{C}_{3} \mathrm{~A}$ and $\mathrm{C}_{3} \mathrm{~A} / \mathrm{C}_{5} \mathrm{~S}_{2} \overline{\mathrm{S}}(1: 2$ by mass $)$ blended pastes are reproduced in Figure 5. As expected, the product of $\mathrm{C}_{3} \mathrm{~A}$ hydration was katoite $\left(\mathrm{C}_{3} \mathrm{AH}_{6}\right)[14,16,19]$. Calcium hemicarboaluminate hydrate, ternesite, katoite, 
200 larnite, $\mathrm{C}_{3} \mathrm{~A} \cdot \mathrm{C} \overline{\mathrm{S}} \cdot 12 \mathrm{H}(\mathrm{AFm})$ and portlandite traces, were identified on XRD pattern of

$201 \mathrm{C}_{3} \mathrm{~A}+$ tenesite paste. The larnite was sourced from the original synthetic ternesite

$202\left(6 \% \mathrm{C}_{2} \mathrm{~S}\right)$. The presence of portlandite traces denoted some minor larnite hydration

203 during the test.

205 The diffractogram for $7 \mathrm{~d}\left(25^{\circ} \mathrm{C}\right) \mathrm{C}_{12} \mathrm{~A}_{7}$ paste contained reflections attributed to $\mathrm{C}_{2} \mathrm{AH}_{8}$,

$206 \mathrm{CAH}_{10}$, gibbsite (very low intensity), and katoite, as well as the anhydrous phase. Two

207 unidentified, low intensity lines at $d=3.48 \AA$ and $d=2.61 \AA$ were also visible on the

208 pattern. The presence of ternesite altered $\mathrm{C}_{12} \mathrm{~A}_{7}$ hydration products. Instead of the

209 reflections observed on the pattern for $\mathrm{C}_{12} \mathrm{~A}_{7}$ paste, the respective diffractogram

210 contained lines generated by strätlingite, larnite, calcium monosulfoaluminate hydrate

211 and ternesite (Figure 6).

212

213 The diffractogram for the $7 \mathrm{~d}\left(25^{\circ} \mathrm{C}\right) \mathrm{CA}$ paste exhibited reflections attributed to $\mathrm{CAH}_{10}$

214 and $\mathrm{C}_{2} \mathrm{AH}_{8}$, gibbsite and katoite (low intensity), as well as to anhydrous CA. These

215 findings were consistent with observations reported by Lothenbach et al. [21, 22]. As

216 the most intense diffraction lines for the metastable phases $\mathrm{C}_{2} \mathrm{AH}_{8}$ and $\mathrm{C}_{4} \mathrm{AH}_{19}$ concur

217 at $\mathrm{d}=10.7 \AA$ and $5.36 \AA$, they cannot be readily differentiated with XRD, even though

218 the relative intensities vary somewhat. These phases are generated by dissolved ions,

219 whereas the metastable hydrates in the $\mathrm{C}_{2} \mathrm{~A} \cdot \mathrm{xH}$ and $\mathrm{C}_{4} \mathrm{~A} \cdot \mathrm{xH}$ series are obtained by

220 dehydration of the ions carrying the most water.

221 The shift observed here in the main reflections for $\mathrm{C}_{2} \mathrm{AH}_{8}(\mathrm{~d}=10.7 \AA$ and $5.36 \AA$ ) to

222 slightly lower values ( $d=10.4 \AA$ and $5.2 \AA$ ) on the diffractograms for pastes $\mathrm{C}_{12} \mathrm{~A}_{7}$ and

223 CA may denote slight sample dehydration due to their exposure to acetone and vacuum

224 drying to detain hydration and remove water [23]. 
225 As in $\mathrm{C}_{12} \mathrm{~A}_{7}$, the presence of ternesite altered CA hydration products. The diffractogram

226 for the blended paste contained none of the reflections observed on the pattern for CA

227 paste, although lines indicative of strätlingite, calcium monosulfoaluminate hydrate,

228 larnite and ternesite were identified (Figure 7).

230 The $\mathrm{C}_{4} \mathrm{~A}_{3} \overline{\mathrm{S}}$ hydration products identified by XRD were AFm and gibbsite (Figure 8), a

231 finding consistent with prior reports [24]. The hemicarboaluminate identified was

232 deemed to be due to sample weathering. Part of the $\mathrm{C}_{4} \mathrm{~A}_{3} \overline{\mathrm{S}}$ was still anhydrous after

2337 days of hydration at $25^{\circ} \mathrm{C}$. The presence of ternesite appeared to stimulate $\mathrm{C}_{4} \mathrm{~A}_{3} \overline{\mathrm{S}}$

234 dissolution, inasmuch as no reflections for this phase were observed on the

235 diffractogram. Here AFm was the reaction product, while no reflections from crystalline

236 aluminium hydroxide was observed.

237 The mineralogical analysis of the hydrated ternesite-containing aluminates based on

238 quantitative XRD is given in Table 5.

\subsection{In-situ XRD}

242 The reactions taking place over time in paste $\mathrm{C}_{12} \mathrm{~A}_{7}+$ ternesite generated a heat flow

243 curve with a number of signals. These reactions were identified by continuous XRD

244 scanning during the first $20 \mathrm{~h}$ of hydration (Figure 9). The intensity of the reflections

245 attributed to $\mathrm{C}_{2} \mathrm{AH}_{8}$ rose over time, whilst the intensity of the lines for $\mathrm{C}_{12} \mathrm{~A}_{7}$ and

246 ternesite declined.

247 The decline in intensity of the main diffraction lines for $\mathrm{C}_{12} \mathrm{~A}_{7}$ and ternesite concurred

248 in time with the first exothermal peak on the calorimetric curve, an indication that these

249 phases dissolved very early into hydration. $\mathrm{C}_{2} \mathrm{AH}_{8}$ was identified as the first hydrate,

250 generated at $10 \mathrm{~min}$, along with $\varphi-\mathrm{AH}_{3}$ (Equation 1). After $1 \mathrm{~h}$ (small exothermal peak 
on the calorimetric curve), the intensity of the diffraction lines for $\mathrm{C}_{12} \mathrm{~A}_{7}$ and ternesite

252 declined again, while that of the $\mathrm{C}_{2} \mathrm{AH}_{8}$ reflections continued to rise. The two reagents

253 declined throughout the induction period. A new phase, $\mathrm{CaAl}_{2} \mathrm{Si}_{7} \mathrm{O}_{18} \cdot 3.5 \mathrm{H}_{2} \mathrm{O}$, appeared

254 after $4.5 \mathrm{~h}$ through the end of the test $(20 \mathrm{~h})$ as a product of the reaction between

255 ternesite and $\varphi-\mathrm{AH}_{3}$. Phase $\varphi-\mathrm{AH}_{3}$, which was identified from the outset, began to

256 gradually decline after $2 \mathrm{~h}$ and disappeared entirely after $5 \mathrm{~h}$, as strätlingite and

$257 \mathrm{CaAl}_{2} \mathrm{Si}_{7} \mathrm{O}_{18} \cdot 3.5 \mathrm{H}_{2} \mathrm{O}$ formed.

258

$\mathrm{C}_{12} \mathrm{~A}_{7}+51 \mathrm{H}_{2} \mathrm{O} \rightarrow 6 \mathrm{C}_{2} \mathrm{AH}_{8}+\mathrm{AH}_{3}$

260 The strätlingite reflections (Equation 2) were identified after $5 \mathrm{~h}$, as $\mathrm{C}_{2} \mathrm{AH}_{8}$ continued to

261 rise and ternesite and $\mathrm{C}_{12} \mathrm{~A}_{7}$ to decline as a result. The absence of reflections for new crystalline sulfates may be explained either by their low crystallinity (with the probable formation of AFm nuclei) or the fact that the sulfate ion resulting from ternesite

264 decomposition remains in solution after strätlingite crystallisation.

265

$2 \mathrm{AH}_{3}+2 \mathrm{C}_{2} \mathrm{~S} \cdot \mathrm{C} \overline{\mathrm{S}}+10 \mathrm{H} \rightarrow 2 \mathrm{C}_{2} \mathrm{SA} \cdot 8 \mathrm{H}_{2} \mathrm{O}+2 \mathrm{C} \overline{\mathrm{S}}$

266

267 Calcium monosulfoaluminate hydrate (Equation 3) appeared at around $9 \mathrm{~h}-10 \mathrm{~h}$,

268 however, concurring with the low intensity, long-lasting exothermal shoulder on the

269 calorimetric curve.

270

$3 \mathrm{C}_{2} \mathrm{~A} \cdot 8 \mathrm{H}_{2} \mathrm{O}+2 \mathrm{C} \overline{\mathrm{S}}+3 \mathrm{H}_{2} \mathrm{O} \rightarrow 2 \mathrm{C}_{3} \mathrm{~A} \cdot \mathrm{C} \overline{\mathrm{s}} \cdot 12 \mathrm{H}+\mathrm{AH}_{3}$ 
272 The same sample was scanned after storage for $7 \mathrm{~d}$ in a moist environment at $25^{\circ} \mathrm{C}$. The

273 diffractogram showed higher intensity strätlingite reflections and AFm phases, whilst no 274 lines for the intermediate phase, $\mathrm{CaAl}_{2} \mathrm{Si}_{7} \mathrm{O}_{18} \cdot 3.5 \mathrm{H}_{2} \mathrm{O}$, were observed. The intensity of

275 the ternesite and $\mathrm{C}_{2} \mathrm{AH}_{8}$ reflections was low, although the latter was still visible. These

276 findings differed in some respects from the $7 \mathrm{~d}\left(25^{\circ} \mathrm{C}\right)$ calorimetric results, where large

277 amounts of unreacted ternesite were observed and no $\mathrm{C}_{2} \mathrm{AH}_{8}$ was identified.

278 The explanation for the differences between the XRD findings for the sample hydrated

279 for $7 \mathrm{~d}$ in the calorimeter and the one hydrated for $20 \mathrm{~h}$ in the diffractometer and

280 subsequently stored at $25^{\circ} \mathrm{C}$ for $6 \mathrm{~d}$ more, might be that in the latter, the incidence of

281 the X-rays on the sample may have induced a temperature substantially higher than 25

$282{ }^{\circ} \mathrm{C}$. That may have given rise to different phases than obtained at a constant $25^{\circ} \mathrm{C}$ and

283 would also explain why the ternesite was largely consumed in $20 \mathrm{~h}$ in the diffractometer

284 whereas a large fraction of the mineral had not reacted after $7 \mathrm{~d}$ at $25^{\circ} \mathrm{C}$ in the

285 calorimeter.

286

287 3.4. FTIR study

288 The FTIR analyses (Table 6) confirmed the XRD results. The infrared spectrum for

289 paste $\mathrm{C}_{3} \mathrm{~A}$ exhibited the absorption lines characteristic of katoite, some (in the $790 \mathrm{~cm}^{-1}$ -

$290820 \mathrm{~cm}^{-1}$ and $520 \mathrm{~cm}^{-1}-530 \mathrm{~cm}^{-1}$ ranges) overlapping with the signals for the remaining

291 anhydrous $\mathrm{C}_{3} \mathrm{~A}[16]$. Slight carboaluminate contamination was likewise observed.

292 The most intense bands on the FTIR for paste $\mathrm{C}_{4} \mathrm{~A}_{3} \overline{\mathrm{S}}$, in the O-H stretching zone

$293\left(4000 \mathrm{~cm}^{-1}-3000 \mathrm{~cm}^{-1}\right)$ were generated by overlapping AFm and gibbsite signals [18].

294 On the rest of the spectrum the bands for these two hydrates were observed to overlap 
with those of anhydrous $\mathrm{C}_{4} \mathrm{~A}_{3} \overline{\mathrm{S}}$ and, to a lesser extent, calcium hemicarboaluminate hydrate $(\mathrm{Hc})$.

297 The spectra for pastes $\mathrm{CA}$ and $\mathrm{C}_{12} \mathrm{~A}_{7}$ exhibited similar bands in the $4000 \mathrm{~cm}^{-1}$ -

$2982500 \mathrm{~cm}^{-1}$ range, although they were sharper in the former, where they were attributed

299 to gibbsite overlapping with katoite, $\mathrm{CAH}_{10}$ and $\mathrm{C}_{2} \mathrm{AH}_{8}$. Overlapped bands generated by

$300 \mathrm{CAH}_{10}, \mathrm{C}_{2} \mathrm{AH}_{8}$ (more intense in $\mathrm{C}_{12} \mathrm{~A}_{7}$ ) and gibbsite (much more intense in $\mathrm{CA}$ )

301 appeared in the $1300 \mathrm{~cm}^{1}-400 \mathrm{~cm}^{-1}$ zone. Some of the bands on these spectra were

302 identified by Fernández-Carrasco et al. [25]. In order to identify more clearly the phases

303 present, these samples were thermally treated at $188^{\circ} \mathrm{C}$, temperature at which $\mathrm{CAH}_{10}$

304 phase is decomposed and $\mathrm{C}_{2} \mathrm{AH}_{8}$ partially lose the water.

305 After the two pastes were heated to $188^{\circ} \mathrm{C}$, the FTIR spectra changed radically: the

$306 \mathrm{CAH}_{10}$ bands disappeared and the $\mathrm{C}_{2} \mathrm{AH}_{8}$ bands were altered due to a partial water loss.

307 The gibbsite bands intensified on the paste CA spectrum and nearly disappeared in

$308 \mathrm{C}_{12} \mathrm{~A}_{7}$, where the signals for katoite and partially dehydrated $\mathrm{C}_{2} \mathrm{AH}_{8}$ intensified. These

309 findings infer that the two pastes contained the same hydrates, albeit in different

310 proportions. CA had more gibbsite and less katoite and $\mathrm{C}_{2} \mathrm{AH}_{8}$ than $\mathrm{C}_{12} \mathrm{~A}_{7}$.

311 The bands attributable to ternesite stood out on the spectra for the four aluminate pastes

312 containing the mineral. They appeared in all the samples at $1153 \mathrm{~cm}^{-1}, 1121 \mathrm{~cm}^{-1}$,

$313947 \mathrm{~cm}^{-1}, 878 \mathrm{~cm}^{-1}, 837 \mathrm{~cm}^{-1}, 660 \mathrm{~cm}^{-1}, 630 \mathrm{~cm}^{-1}, 602 \mathrm{~cm}^{-1}, 541 \mathrm{~cm}^{-1}$ and $517 \mathrm{~cm}^{-1}$ [26],

314 i.e., in the $1300 \mathrm{~cm}^{-1}-400 \mathrm{~cm}^{-1}$ range, where no other anhydrous phase absorptions were

315 observed. All four spectra exhibited a narrow, intense absorption signal at $424 \mathrm{~cm}^{-1}$ and

316 other wider, overlapping signals at around $520 \mathrm{~cm}^{-1}$ and $540 \mathrm{~cm}^{-1}$, characteristic of a

317 number of calcium aluminate hydrates. The ternesite spectrum (multiplied by a factor of

318 0.4-0.8) was subtracted from the original paste spectra to better identify the hydrates. 
319 The spectra for paste $\mathrm{C}_{3} \mathrm{~A}+$ ternesite (Figure 10) exhibited bands in the O-H stretching

320 vibrations zone mainly generated by the presence of Hc overlapped with bands from

321 AFm and portlandite while the $\mathrm{O}-\mathrm{H}$ stretching band from katoite was not clearly

322 ditinguisted, After subtracting ternesite spectra, the most prominent bands in the 1300-

$323400 \mathrm{~cm}^{-1}$ range were attributed to AFm (at $\left.\approx 1110,784,539,424 \mathrm{~cm}^{-1}\right)$ and Hc.

324 The spectrum for paste $\mathrm{C}_{12} \mathrm{~A}_{7}+$ ternesite (Figure 11) exhibited $\mathrm{O}-\mathrm{H}$ stretching vibrations generated by water and hydrates, attributed to $\operatorname{AFm}\left(3670 \mathrm{~cm}^{-1}\right)$, as well as a wide band with two peaks, at $3615 \mathrm{~cm}^{-1}$ and $3530 \mathrm{~cm}^{-1}$ (possibly indicative of a weatheringinduced hemicarboaluminate). The bands remaining after the ternesite spectrum was

328 subtracted, all in the $1300 \mathrm{~cm}^{-1}-400 \mathrm{~cm}^{-1}$ range, were attributable to $\mathrm{C}_{2} \mathrm{ASH}_{8}$ $\left(1013 \mathrm{~cm}^{-1}, 964 \mathrm{~cm}^{-1}, 710 \mathrm{~cm}^{-1}\right)$ or AFm $\left(780 \mathrm{~cm}^{-1}, 572 \mathrm{~cm}^{-1}, 539 \mathrm{~cm}^{-1}\right)$. A band overlapping generously with ternesite attributable to AFm was observed in the sulfate $v_{3}$ zone.

332 The spectra for paste CA+ternesite (Figure 12) were very similar to the ones for

$333 \mathrm{C}_{12} \mathrm{~A}_{7}+$ ternesite, with $\mathrm{O}-\mathrm{H}$ stretching vibrations from water and hydrates attributed to $334 \operatorname{AFm}\left(3670 \mathrm{~cm}^{-1}\right)$, although an intense band appeared at $3622 \mathrm{~cm}^{-1}$, along with a wide 335 band at $3559 \mathrm{~cm}^{-1}-3487 \mathrm{~cm}^{-1}$, which overlapped with another at $3550 \mathrm{~cm}^{-1}$, which could 336 be assigned to $\mathrm{AH}_{3}$. The bands observed in the $1300 \mathrm{~cm}^{-1}-400 \mathrm{~cm}^{-1}$ range on the post337 subtraction spectrum at around $1013 \mathrm{~cm}^{-1}, 964 \mathrm{~cm}^{-1}$ and $710 \mathrm{~cm}^{-1}$, attributable to

$338 \mathrm{C}_{2} \mathrm{ASH}_{8}$, were much more intense than on the $\mathrm{C}_{12} \mathrm{~A}_{7}$ spectrum. Less intense bands 339 generated by AFm were found at $780 \mathrm{~cm}^{-1}, 572 \mathrm{~cm}^{-1}$ and $539 \mathrm{~cm}^{-1}$.

340 The spectra for paste $\mathrm{C}_{4} \mathrm{~A}_{3} \overline{\mathrm{S}}+$ ternesite (Figure 13) also contained $\mathrm{O}-\mathrm{H}$ stretching vibrations from water and hydrates that concurred with the signals for gibbsite, although 
342 their relative intensities differed. The most prominent band in the $1300 \mathrm{~cm}^{-1}-400 \mathrm{~cm}^{-1}$

343 range on the spectrum resulting from subtracting the ternesite bands, at $1020 \mathrm{~cm}^{-1}$, was

344 characteristic of gibbsite, which had not been identified by XRD. Signals attributed to

345 AFm were observed at $780 \mathrm{~cm}^{-1}, 582 \mathrm{~cm}^{-1}$ and $539 \mathrm{~cm}^{-1}$.

\subsection{DTA-TG study}

The water content in $7 \mathrm{~d}$ aluminate pastes was: $\mathrm{CA}>\mathrm{C}_{12} \mathrm{~A}_{7}>\mathrm{C}_{4} \mathrm{~A}_{3} \overline{\mathrm{S}}>\mathrm{C}_{3} \mathrm{~A}$. The order for the pastes containing ternesite (normalised per g of dry aluminate), which held less water, was $\mathrm{CA}>\mathrm{C}_{12} \mathrm{~A}_{7}>\mathrm{C}_{3} \mathrm{~A}>\mathrm{C}_{4} \mathrm{~A}_{3} \overline{\mathrm{S}}$ (Figure 14).

352

353

354

355

Assigning thermal signals to calcium aluminate hydrate dehydration/dehydroxylation in poly-phase samples is a complex task, for each phase holds various forms of bound water, which may be gradually released with rising heat. As a result, each phase generates several endothermal signals in the same temperature ranges, which explains the lack of uniformity in the literature cited in Table 7.

The most prominent, i.e., most intense and sharpest, of the endothermal dehydration and dehydroxylation peaks for the hydrates in the pastes studied was attributed to katoite, at $300{ }^{\circ} \mathrm{C}$ on the DTA curve for paste $\mathrm{C}_{3} \mathrm{~A}$. This peak was also observed, vaguely and overlapping with gibbsite, on the curves for pastes $\mathrm{CA}$ and $\mathrm{C}_{12} \mathrm{~A}_{7}$. Further to the TG findings, hydrated paste $\mathrm{C}_{3} \mathrm{~A}$ contained $79 \mathrm{wt} \%$ katoite and $21 \mathrm{wt} \%$ anhydrous $\mathrm{C}_{3} \mathrm{~A}$. In other words, the hydration rate in $\mathrm{C}_{3} \mathrm{~A}$ was 0.73 .

The DTA curves for pastes CA and $\mathrm{C}_{12} \mathrm{~A}_{7}$ (Figure 15) exhibited several thermal signals at temperatures of under $200{ }^{\circ} \mathrm{C}$ and in the $200{ }^{\circ} \mathrm{C}-600{ }^{\circ} \mathrm{C}$ range, all associated with weight loss on the TG/DTG curves (Figure 14). In the first range of temperatures the 
intense endothermal peaks at around $80{ }^{\circ} \mathrm{C}-88^{\circ} \mathrm{C}$ were attributed to amorphous $\mathrm{AH}_{3}$

[33]. They overlapped with a peak at around $100{ }^{\circ} \mathrm{C}-110{ }^{\circ} \mathrm{C}$, generated by water loss

370 from $\mathrm{CAH}_{10}$ and the water physically adsorbed on the $\mathrm{C}_{2} \mathrm{AH}_{8}$ interlayer. Another endothermal signal at around $145^{\circ} \mathrm{C}-160{ }^{\circ} \mathrm{C}$ could be attributed to further partial water loss from $\mathrm{C}_{2} \mathrm{AH}_{8}$ [35]. In the second temperature range, the DTA curves for both pastes exhibited endothermal signals of varying intensity at around $260{ }^{\circ} \mathrm{C}, 280{ }^{\circ} \mathrm{C}$ and $320^{\circ} \mathrm{C}$, attributed to water loss from $\mathrm{C}_{2} \mathrm{AH}_{8}, \mathrm{AH}_{3}$ and $\mathrm{C}_{3} \mathrm{AH}_{6}$. Two much less intense signals at $421{ }^{\circ} \mathrm{C}$ and $524^{\circ} \mathrm{C}$ were also attributed to those phases.

376

The DTA curves for sample $\mathrm{C}_{4} \mathrm{~A}_{3} \overline{\mathrm{S}}$ (Figure 16) contained very intense $<200{ }^{\circ} \mathrm{C}$ signals: at 120 and $180{ }^{\circ} \mathrm{C}$ for $\mathrm{AFm}$ and $120^{\circ} \mathrm{C}$ overlapped with hemicarboaluminate, the latter due to sample weathering. Three peaks were observed at $200{ }^{\circ} \mathrm{C}-300{ }^{\circ} \mathrm{C}$, the most intense at $264{ }^{\circ} \mathrm{C}$ and the others at $224^{\circ} \mathrm{C}$ and 286 , which might be due to AFm, Hc and gibbsite overlapping. The peak at $286^{\circ} \mathrm{C}$ was associated with gibbsite water loss.

$\mathrm{C}_{3} \mathrm{~A}+$ ternesite curve (Figure 17$)$ contained an intense broad $\left(120-180^{\circ} \mathrm{C}\right)$ endothermal signal, peaking at around $154^{\circ} \mathrm{C}$ and other broad one at $240{ }^{\circ} \mathrm{C}$, denoting water loss from $\mathrm{Hc}$ and AFm. The signal at $285{ }^{\circ} \mathrm{C}$ was generated by Katoite and the final one at $412^{\circ} \mathrm{C}$ by portlandite, as per Torréns-Martín et al. [39].

387 Curves for $\mathrm{CA}, \mathrm{C}_{12} \mathrm{~A}_{7}$ and $\mathrm{C}_{4} \mathrm{~A}_{3} \mathrm{~S}$ with ternesite pastes exhibited a very intense endothermal signal at around $170{ }^{\circ} \mathrm{C}-180{ }^{\circ} \mathrm{C}$ generated by water loss from AFm phases.

390 The curves for samples $\mathrm{CA}+$ ternesite and $\mathrm{C}_{12} \mathrm{~A}_{7}+$ ternesite (Figure 18) had endothermal signals of varying intensity at around $125^{\circ} \mathrm{C}-128^{\circ} \mathrm{C}, 170^{\circ} \mathrm{C}$ and $220^{\circ} \mathrm{C}$, attributable to

392 strätlingite, according to Kuzel [36] and Matschei [40], and as regards the signal at

$393170{ }^{\circ} \mathrm{C}$, also to $\mathrm{AFm}$. The conclusion that could be drawn from a comparison of the 
394 intensity of these signals is that CA+ternesite had a higher proportion of strätlingite and

395 paste $\mathrm{C}_{12} \mathrm{~A}_{7}+$ ternesite a higher proportion of $\mathrm{AFm}$. That finding is consistent with the

396 FTIR and XRD results. These two pastes also exhibited a much lower intensity

397 endothermal signal at $285^{\circ} \mathrm{C}$ that might be associated with $\mathrm{AH}_{3}$ water loss, although the

398 XRD analyses failed to identify that phase.

399

400 In addition to the aforementioned AFm and hemicarboaluminate signals at $170{ }^{\circ} \mathrm{C}$,

$401210{ }^{\circ} \mathrm{C}$ and $110^{\circ} \mathrm{C}$, the $\mathrm{C}_{4} \mathrm{~A}_{3} \overline{\mathrm{S}}+$ ternesite sample exhibited others attributable to gibbsite

402 overlapped with AFm, which generated two peaks, at $250{ }^{\circ} \mathrm{C}$ and $290{ }^{\circ} \mathrm{C}$ (Figure 19).

403

404

\section{Discussion}

405

406

The calorimetric curves for the hydrated aluminate pastes contained a first dissolution

407 peak, followed by an induction period and an intense reaction peak in pastes $\mathrm{CA}, \mathrm{C}_{12} \mathrm{~A}_{7}$ and $\mathrm{C}_{4} \mathrm{~A}_{3} \overline{\mathrm{S}}[17,18,21]$ The presence of ternesite in the pastes altered the calorimetric curves in all cases, shortening the induction period and bringing the reaction peak

410 forward.

411 The pastes containing $\mathrm{C}_{12} \mathrm{~A}_{7}$ had a much more active induction period than any of the

412 others, with a heat flow a full order or magnitude higher. $\mathrm{C}_{2} \mathrm{AH}_{8}$ and $\varphi-\mathrm{AH}_{3}$ formed

413 from the onset of hydration in pastes with ternesite, which reacted with $\varphi-\mathrm{AH}_{3}$ in the

414 induction period, giving rise to an intermediate phase, $\mathrm{CaAl}_{2} \mathrm{Si}_{7} \mathrm{O}_{18} \cdot 3.5 \mathrm{H}_{2} \mathrm{O}$. In the main

415 exothermal peak concurred the consumption of all the $\varphi-\mathrm{AH}_{3}$ and the first strätlingite

416 crystallization, while $\mathrm{C}_{2} \mathrm{AH}_{8}$ precipitation as well as reagents dissolution (ternesite and

$417 \quad \mathrm{C}_{12} \mathrm{~A}_{7}$ ) continued. The main reaction peak was followed by calcium

418 monosulfoaluminate hydrate precipitation. $\mathrm{C}_{12} \mathrm{~A}_{7}$ can therefore be regarded to

419 powerfully activate ternesite, which dissolved from the outset, giving rise to calcium 
silicoaluminate hydrate precipitation even prior to calcium monosulfoaluminate

421 precipitation.

422 Whilst the $7 \mathrm{~d}$ aluminate+ternesite (1:2) pastes released less total heat than the analogous unblended aluminate pastes, however when total heat was expressed per unit

424 of mass of aluminate, the four samples containing ternesite exhibited higher values than 425 their unblended aluminate counterparts. The inference is that ternesite participate in the 426 hydration reactions and not only hastened but activated aluminate hydration. In the 427 presence of ternesite, the amount of heat per aluminate mass unit rose by $91 \%$ in CA, $87 \%$ in $\mathrm{C}_{12} \mathrm{~A}_{7}, 19 \%$ in $\mathrm{C}_{3} \mathrm{~A}$ and $36 \%$ in $\mathrm{C}_{4} \mathrm{~A}_{3} \overline{\mathrm{S}}$ (Table 4).

429 Ternesite is activated when hydrated in the presence of $\mathrm{C}_{3} \mathrm{~A}, \mathrm{C}_{12} \mathrm{~A}_{7}$ and $\mathrm{CA}$, accounting 430 for $43 \mathrm{wt} \%$ to $22 \mathrm{wt} \%$ of the respective pastes, according to XRD data. On the grounds 431 of the quantitative XRD findings in conjunction with the total mass loss at $1000{ }^{\circ} \mathrm{C}$ 432 determined with TG, $16 \mathrm{wt} \%$ of the ternesite reacted in $\mathrm{C}_{3} \mathrm{~A}, 50 \mathrm{wt} \%$ in CA and $53 \mathrm{wt} \%$ 433 in $\mathrm{C}_{12} \mathrm{~A}_{7}$. Those results denote scant (2\%) ternesite reaction in the ternesite-ye'elemite 434 blended paste.

$435 \mathrm{C}_{3} \mathrm{~A}$ hydration, which was incomplete after $7 \mathrm{~d}$ (hydration degree $=0,73$ ), yielded 436 katoite (Equation 4). Further to the XRD findings, $\mathrm{C}_{3} \mathrm{~A}$ hydration in the presence of 437 ternesite produces a small amounts of katoite ( $5.36 \mathrm{wt} \%$ ) calcium monosulfoaluminate 438 hydrate ( $1.76 \mathrm{wt} \%)$ and calcium hemicarboaluminate hydrate ( $6.91 \mathrm{wt} \%$ ) as well as 439 larnite ( $1.71 \mathrm{wt} \%)$, ternesite $(43.11 \mathrm{wt} \%), \mathrm{C}_{3} \mathrm{~A}(0.72 \mathrm{wt} \%)$ as the main crystalline 440 phases and amorphous phases (40.42 wt\%).

441

$$
\mathrm{C}_{3} \mathrm{~A}+6 \mathrm{H}_{2} \mathrm{O} \rightarrow \mathrm{C}_{3} \mathrm{AH}_{6}
$$


443 Calculus derivated from DRX an TG data reveal a scant reaction of ternesite $(16,3 \mathrm{wt} \%)$

444 while $\mathrm{C}_{3} \mathrm{~A}$ reacted almost completely $(97 \mathrm{wt} \%)$. These data fit very well with the

445 increment of the total heat released per aluminate mass unit in this paste (Table 4).

447 Taken into account the loss of mass recorded by TG, it can be concluded that $\mathrm{C}_{3} \mathrm{~A}$ plus

448 ternesite paste contains $28,7 \mathrm{wt} \%$ of $\mathrm{AFm}+\mathrm{Hc} ; 11,5 \mathrm{wt} \%$ of $\mathrm{C}_{3} \mathrm{AH}_{6}$ and $1,6 \mathrm{wt} \%$ de

449 portlandita; these values are very much more higher than those determined by XRD,

450 which would be an indication of the poor crystallinity of the hydrates obtained.

451 Pastes $\mathrm{C}_{12} \mathrm{~A}_{7}$ and $\mathrm{CA}$ gave rise to the same hydration products, $\mathrm{CAH}_{10}, \mathrm{C}_{2} \mathrm{AH}_{8}$ and $\mathrm{AH}_{3}$, 452 although in different proportions, in addition to the respective anhydrous aluminates. In 453 the presence of ternesite the anhydrous aluminates reacted fully, generating AFm and $454 \mathrm{C}_{2} \mathrm{ASH}_{8}$ in both cases. No other calcium aluminate hydrate appeared as a crystalline 455 phase.

456 Combining TG and XRD data the amount of ternesite consumed in samples $\mathrm{C}_{12} \mathrm{~A}_{7}+$ 457 ternesite and CA + ternesite, is respectively 53\% and 50\%; assuming that all the sulfate 458 of the dissolved ternesite forms AFm and all the remaining aluminum forms strätlingite, 459 the proportions of these phases was calculated which are shown in Table 8. Both 460 hydrates would be in much higher proportion than that shown by XRD, however the 461 results are consistent with the mass loss observed by TG, which would account for the 462 poor crystallinity of AFm and strätlingite in said pastes.

463 The hydration products for paste $\mathrm{C}_{4} \mathrm{~A}_{3} \overline{\mathrm{S}}$ included $\mathrm{AFm}(33 \%)$ and $\mathrm{AH}_{3}(43 \%)$ (small 464 signal of hemicarboaluminate was also observed) (Eq.5).

$$
\mathrm{C}_{4} \mathrm{~A}_{3} \overline{\mathrm{S}}+12 \mathrm{H}_{2} \mathrm{O} \rightarrow \mathrm{C}_{4} \mathrm{~A} \overline{\mathrm{S}} \mathrm{H}_{12}+2 \mathrm{AH}_{3}\left(+\mathrm{C}_{4} \mathrm{AcH}_{11}\right)
$$

466

467 The XRD and TG findings showed that in the presence of ternesite, around 3 wt $\%$ of

468 the ye'elemite remained unreacted. AFm appeared and $\mathrm{AH}_{3}$ was identified by FTIR and 
DTA, although not on the X-ray diffractograms, an indication of its amorphous nature.

470 These findings do not infer that ye'elemite acted as a ternesite activator, for no

471 strätlingite was identified. As noted earlier, further to calculations based on the ternesite

472 content $(50.5 \mathrm{wt} \%)$, the total TG-determined mass loss $(17.6 \mathrm{wt} \%)$ and the

473 ye'elemite:ternesite ratio, the sample contained $97.8 \%$ of the ternesite initially added.

474 That was very likely due to the common sulfate ion effect, which delayed ternesite

475 dissolution. Under such circumstances, ternesite would affect the crystallinity of the

$476 \mathrm{AH}_{3}$ formed (gibbsite in the ye'elemite paste and amorphous aluminium hydroxide in

477 yeelemite+ ternesite paste) and the ye'elemite hydration rate (shortening the induction

478 period), but the amount of ternesite consumed along the reaction time was very low.

479 The calorimetric data nonetheless revealed a $36 \%$ rise in the total heat per unit of

480 aluminate released, perhaps due to the filler effect.

481 The crystalline AFm of ternesite plus ye'elemite paste content was also very low,

482 inasmuch as $96 \mathrm{wt} \%$ of the ye'elemite reacted. The hydrate content determined with

483 XRD and the calculated using the degree of reaction for ternesite and ye'elemite is

484 given in Table 8 . The table also lists the mass loss in the four pastes at $1000{ }^{\circ} \mathrm{C}$

485 calculated from those data and from the TG findings.

486 As XRD identified crystalline $\mathrm{AH}_{3}$ in the ternesite-free paste but not in the paste

487 bearing ye'elemite + TER, the presence of ternesite may be deduced to have affected

488 both $\mathrm{AFm}$ and $\mathrm{AH}_{3}$ crystallinity.

489

490 The XRD-determined crystalline AFm content in the pastes was much lower than would

491 be expected on the grounds of the reaction degree of ternesite and aluminates. The

492 calculated loss of evaporable matter in the hydrates was much higher than calculated

493 with the XRD data and very close to the TG findings. A substantial portion of the AFm 
may consequently be assumed to be scantly crystalline and included in the amorphous

495 phase determined in XRD patterns.

496

497

498

\section{Conclusions}

499

500 This study explored the possible activation of ternesite hydration by a series of

501 aluminates by recording heat of hydration and analysing the $7 \mathrm{~d}$ hydration products with

502 XRD, FTIR and DTA. The ultimate aim was to pave the way for the future development

503 of a new eco-clinker, in which one of the main minerals would be ternesite blended with

504 aluminates that would activate its hydration. The major conclusions are listed below.

505

506 - Ternesite was activated in all the blends, although with varying intensity depending on

507 the aluminate added. Aluminate efficacy was, in descending order, $\mathrm{C}_{12} \mathrm{~A}_{7} \approx \mathrm{CA}$

508

$>\mathrm{C}_{3} \mathrm{~A} \gg>>\mathrm{C}_{4} \mathrm{~A}_{3} \overline{\mathrm{s}}$

509

510 - The presence of ternesite in the pastes altered the aluminate heat flow curves,

511 shortening the induction period and bringing the reaction peak forward, an indication of

512 hastened hydration. The calorimetric findings revealed rises of $19 \%$ to $91 \%$ in total

513 heat release per unit of aluminate mass, attesting to the activation of aluminate

514 hydration in the presence of ternesite.

515

516 - Hydration of $\mathrm{C}_{3} \mathrm{~A}$ produces Katoite as the only hydration product but in presence of

517 ternesite the katoite amount is hardly reduced while AFm and Hemicarboaluminate

518 were found. 
$519-\mathrm{C}_{12} \mathrm{~A}_{7}$ and $\mathrm{CA}$ were analysed jointly, for they yielded the same hydration products.

520 These aluminates activated ternesite hydration and their pastes contained the same

521 phases (AFm and stratlingite), albeit in different proportions..

522

523 - Due to the common sulfate ion effect, much less ternesite (2 wt \%) was consumed in

524 paste $\mathrm{C}_{4} \mathrm{~A}_{3} \overline{\mathrm{S}}$ than in any of the other samples. However ternesite alter the cristallinity of

525 the obtained hydrates; scantly crystalline $\mathrm{AFm}$ and amorphous $\mathrm{AH}_{3}$ were the main

526 hydration products in this paste. As no strätlingite was obtained, ternesite could not be

527 regarded as having been clearly activated by ye'elemite, despite some calorimetric

528 evidence to that effect.

529 Acknowledgements.

530

531 This paper has been funded from BIA2016-76466-R project as well as the Regional

532 Government of Madrid Community and European Social Fund (Geomaterials

533 Programme2 S2013/MIT-2914). Authors thank to Ministerio de Economía y

534 Competitividad the young resercher contract given to Myriam Montes. Financial

535 support for Dr. Paula M. Carmona-Quiroga's participation was provided by the Spanish

536 Ministry of the Economy and Competitiveness under project BIA2015-73237-JIN.

$538 \quad$ References

539 [1] O. Edenhofer, et al. IPCC, 2014: Climate Change 2014: Mitigation of Climate

540 Change. Contribution of Working Group III to the Fifth Assessment Report of the

541 Intergovernmental Panel on Climate Change (2014)

542 [2] Marta García Maté. Processing and Characterisation of calcium sulphoaluminate

543 (CSA) eco-cement with taylored performances. (2014) PhD University of Málaga 
544 [3] M. Carmen Martín-Sedeño, Antonio J.M. Cuberos, Ángeles G. De la Torrea, Gema

545 Álvarez-Pinazo, Luis M. Ordónez; Milen Gateshkic, Miguel A.G. Aranda. Aluminum-

546 rich belite sulfoaluminate cements: Clinkering and early age hydration. Cement and

547 Concrete Research Volume 40, Issue 3, March (2010) 359-369

548 [4] K. Morsli, A.G. de la Torre, M. Zahir, M.A.G. Aranda. Mineralogical phase analysis 549 of alkali and sulfate bearing belite rich laboratory clinkers. Cem. Concr. Res., 37 (2007)

$550 \quad 639-646$

551 [5] M.Marroccoli, F.Montagnaro,M.L. Pace, A. Telesca, G.L. Valenti, Synthesis of 552 calcium sulfoaluminate cements from blends of coal combustion ashes with flue gas 553 desulfurization gypsum, PTSE, Ischia, Italy, 2010.

554 [6] Bullerjahn, F., Zajac, M. \& Ben Haha, M. CSA raw mix design: effect on clinker 555 formation and reactivity. Materials and Structures, Volume 48, (2015) 3895-3911.

556 [7] Bullerjahn, F., Schmitt, D. \& Ben Haha, M. Effect of raw mix design and of 557 clinkering process on the formation and mineralogical composition of (ternesite) belite 558 calcium sulphoaluminate ferrite clinker.Cement and Concrete Research, Volume 59, 559 (2014) 87-95.

560 [8] T. Hanein, I. Galan, F. P. Glasser, S.Skalamprinos, A. Elhoweris, M.S. Imbabi, M.N.

561 Bannerman, Stability of ternesite and the production at scale of ternesite-based clinkers

562 Cement and Concrete Research 98 (2017) 91-100

563 [9] Sherman, N., Beretka, J., Santoro, L. \& Valenti, G. L. Long-term behaviour of 564 hydraulic binders based on calcium sulfoaluminate and calcium sulfosilicate. Cement 565 and Concrete Research (CCR), Volume 25, (1995)113-126.

566 [10] .B. Pliego-Cuervo, F.P. Glasser, The role of sulphates in cement clinkering:

567 subsolidus phase relations in the system $\mathrm{CaO}-\mathrm{Al} 2 \mathrm{O} 3-\mathrm{SiO} 2-\mathrm{SO} 3$. Cem. Concr. Res., 9 568 (1979) 51-56 
569 [11] Mohsen Ben Haha, Frank Bullerjahn, Maciej Zajac "On the reactivity of

570 ternesite” XIV ICCC, Pekín 2015

571 [12] Peter K. Holt, Geoffrey W. Barton, Mary Wark, Cynthia A. Mitchell. A

572 quantitative comparison between chemical dosing and Electrocoagulation.Colloids and

573 Surfaces A: Physicochem. Eng. Aspects 211 (2002) 233-248.

574 [13] H.M. Rietveld, A profile refinement method for nuclear and magnetic structures, J.

575 Appl. Crystallogr. 2 (1969) 65-71.

576 [14] A.C. Larson, R.B. Von Dreele, General Structure Analysis System (GSAS)

577 program, Rep. No. LA-UR-86748, Los Alamos National Laboratory, Los Alamos, CA, 5781994.

579 [15] M. A. G. Aranda, A. G. De la Torre. Rietveld Quantitative Phase Analysis of OPC

580 Clinkers, Cements and Hydration Products. Reviews in Mineralogy \& Geochemistry

$581 \quad$ Vol. 74 pp. 169-209 (2012)

582 [16] S. Gismera-Diez, B. Manchobas-Pantoja, P.M. Carmona-Quiroga, M.T. Blanco-

583 Varela, Effect of BaCO3 on C3A hydration Cement and Concrete Research, 73 (2015)

$584 \quad 70-78$.

585 [17] B. Raab, H. Poellmann, Heat flow calorimetry and SEM investigations to

586 characterize the hydration at different temperatures of different $12 \mathrm{CaO} \cdot \mathrm{A} 12 \mathrm{O} 3(\mathrm{C} 12 \mathrm{~A} 7)$

587 samples synthesized by solid state reaction, polymer precursor process and glycine

588 nitrate process Thermochimica Acta 513 (2011) 106-111

589 [18] M.J. Sánchez-Herrero, A. Fernández-Jiménez, A. Palomo, $\mathrm{C}_{4} \mathrm{~A}_{3} \overline{\mathrm{S}}$ hydration in

590 different alkaline media, Cement and Concrete Research 46 (2013) 41-49

591 [19] E. Breval, C3A Hydration, Cement and Concrete Research, 6 (1976)129-138

592 [20] J.I. Bhatty, A review of the application of thermal analysis to cement-admixture,

593 Systems Thermochimica Acta 189 (1991) 313-350 
594 [21] S.R. Klaus, J. Neubauer, F. Goetz-Neunhoeffer, Hydration kinetics of CA2 and

595 CA-Investigations performed on synthetic calcium aluminate cement, Cement and 596 Concrete Research 43 (2013) 62-69

597 [22] B. Lothenbach, L. Pelletier-Chaignat, F. Winnefeld, Stability in the system CaO598 Al2O3-H2O, Cement and Concrete Research 42 (2012) 1621-1634

599 [23] T.R. Jensena, A. Nbrlund Christensenb, J.C. Hansonc, Hydrothermal

600 transformation of the calcium aluminum oxide hydrates $\mathrm{CaAl} 2 \mathrm{O} 4 \mathrm{~d} \cdot 10 \mathrm{H} 2 \mathrm{O}$ and

$601 \mathrm{Ca} 2 \mathrm{Al} 2 \mathrm{O} 5 \mathrm{~d} \cdot 8 \mathrm{H} 2 \mathrm{O}$ to $\mathrm{Ca} 3 \mathrm{Al} 2(\mathrm{OH}) 12$ investigated by in situ synchrotron X-ray powder

602 diffraction, Cement and Concrete Research 35 (2005) 2300-2309

603 [24] F.P. Glasser, L. Zhang, High-performance cement matrices based on calcium

604 sulfoaluminate-belite compositions, Cement and Concrete Research 31 (2001) 18816051886

606 [25] L. Fernández-Carrasco, D. Torrens-Martín, L.M. Morales, S. Martínez- Ramírez, 607 Infrared Spectroscopy in the Analysis of Building and Construction Materials, Infrared 608 Spectroscopy, Materials Science, Engineering and Technology (2012) 369-382

609 [26] N.V. Chukanov, Infrared spectra of mineral species (2014) Ed Springer

610 [27] S.M. Bushnell-Watson, J.H. Sharp, The application of thermal analysis to the 611 hydration and conversión Reactions of calcium aluminate Cements, Materiales de 612 construcción 42 (1998) 13-32

613 [28] C.M.George, Industrial alumina cement, Structure and Performance of Cement $614 \quad(1983) 415$

615 [29] L. Fernandez Carrasco, Procesos de hidratación y carbonatación del cemento de 616 aluminatos de calcio; influencia de los álcalis. Alteraciones microestructurales y 617 relación con sus propiedades mecánicas. Thesis Instituto de la Construcción Eduardo 618 Torroja, Madrid, Spain, 2000 
619 [30] N. Ukrainczyk, T. Matusinovic, S. Kurajica, B. Zimmermann, J. Sipusic,

620 Dehydration of a layered double hydroxide - C2AH8N, Thermodinamic Acta 464

$621 \quad(2007) 7-15$

622 [31] V.S. Ramachandran, Thermal analysis of cement components hydrated in the 623 presence of calcium carbonate, Thermodinamic Acta 127 (1988) 385-394

624 [32] P.A. Barnes, D.J. Baxter, A critical analysis of the application of derivative

625 thermogravimetry to the determination of the degree of conversion of high alumina 626 cement, Thermochimica Acta 24 (1978) 427-431

627 [33] J. Szczerba, D. Madej, E. Sniezek, R. Prorok, The application of DTA and TG 628 methods to investigate the non-crystalline hydration products of $\mathrm{CaA} 2 \mathrm{O} 4$ and 629 Ca7ZrAl6O18 compounds, Thermochimica Acta 567 (2013) 40- 45

630 [34] C. Gosselin, Microstructural Development of Calcium Aluminate Cement Based 631 Systems with and without Supplementary Cementious Materials, Thesis École 632 Polytechnique Fédérale de Lausanne, Lausanne, Switzerland (2009)

633 [35] V.S. Ramachandran, R.M. Paroli, J.J. Beaudoin, A.H. Delgado, Handbook of 634 Thermal Analysis of Construction Materials, ed.W.A.Publishing.2003, Norwich, New 635 York, U.S.A

636 [36] H.J. Kuzel, Crystallographic data and thermal decomposition of synthetic gehlenite 637 hydrate $2 \mathrm{CaO} \cdot \mathrm{Al} 2 \mathrm{O} 3 \cdot \mathrm{SiO} 2 \cdot 8 \mathrm{H} 2 \mathrm{O}$, Neues Jahrbuch fuer Mineralogie Monatshefte 148 638 (1976) 319-325

639 [37] T. Danner, H. Justnes, M. Geiker, R.A. Lauten, Early hydration of C3A-gypsum 640 pastes with Ca- and Na-lignosulfonate, Cement and Concrete Research 79 (2016) 333641 343 
642 [38] F. Sáez del Bosque I. Modificaciones nanoestructurales en pastas de cemento.

643 Thesis Instituto de Ciencias de la Construcción Eduardo Torroja (CSIC) and

644 Universidad Autonoma de Madrid, Madrid, Spain (2012).

645 [39] D. Torréns-Martín, L. Fernandez-Carrasco, M.T. Blanco-Varela, Thermal analysis

646 of blended cements, Journal of Thermal Analysis calorimetric 121 (3) (2015)

647 [40] T. Matschei. Thermodynamic properties of Portland cement hydrates in the system

$648 \mathrm{CaO}-\mathrm{Al} 2 \mathrm{O} 3-\mathrm{SiO} 2-\mathrm{CaSO} 4-\mathrm{CaCO} 3-\mathrm{H} 2 \mathrm{O}$, Cement and Concrete Research 37 (2007)

$649 \quad 1379-1410$

650 
Table 1. Particle size distribution parameters determined by laser diffraction

653

654

655

656

657

658

659

660

\begin{tabular}{|c|c|c|c|c|c|c|c|c|c|}
\cline { 2 - 10 } \multicolumn{1}{c|}{$\mathrm{C}_{5} \mathrm{~S}_{2} \overline{\mathrm{S}}$} & $\mathrm{C}_{2} \mathrm{~S}$ & $\mathrm{C}_{3} \mathrm{~A}$ & $\mathrm{C}_{12} \mathrm{~A}_{7}$ & $\mathrm{CaO}$ & $\mathrm{CA}$ & $\mathrm{C}_{4} \mathrm{~A}_{3} \overline{\mathrm{s}}$ & $\mathrm{C} \overline{\mathrm{S}}$ & $\mathrm{Rwp}$ \\
\hline $\mathrm{C}_{5} \mathrm{~S}_{2} \overline{\mathrm{S}}$ & 94 & 6 & & & & & & & 10 \\
\hline $\mathrm{C}_{3} \mathrm{~A}$ & & & 100 & & & & & & 16.52 \\
\hline $\mathrm{C}_{12} \mathrm{~A}_{7}$ & & & & 99.82 & 0.18 & & & & 16.99 \\
\hline $\mathrm{CA}$ & & & & 2.52 & & 97.48 & & & 14.12 \\
\hline $\mathrm{C}_{4} \mathrm{~A}_{3} \overline{\mathrm{S}}$ & & & & 1.30 & & & 97.98 & 0.70 & 15.63 \\
\hline ICSD card & 85123 & \multirow{2}{*}{81096} & \multirow{2}{*}{1841} & 241243 & 52783 & 260 & 80361 & \multirow{2}{*}{16382} & \\
\hline
\end{tabular}

Table 3. Data for the heat flow curves shown in Figure 3

\begin{tabular}{|c|c|c|c|c|c|c|c|c|c|}
\hline & \multirow{2}{*}{$\begin{array}{l}\text { Initial peak } 1 \\
\begin{array}{c}\text { Heat flow } \\
(\mathrm{mW} / \mathrm{g})\end{array}\end{array}$} & \multicolumn{2}{|c|}{$\begin{array}{l}\text { Peak } 2 \\
\text { maximum }\end{array}$} & \multicolumn{2}{|c|}{$\begin{array}{l}\text { Min induction } \\
\text { period }\end{array}$} & \multicolumn{2}{|c|}{$\begin{array}{c}\text { Peak } 3 \\
\text { maximum }\end{array}$} & \multicolumn{2}{|c|}{$\begin{array}{l}\text { Maximum } \\
\text { exothermal } \\
\text { signal }\end{array}$} \\
\hline & & $\begin{array}{c}t \\
(h)\end{array}$ & $\begin{array}{l}\text { Heat fl. } \\
(\mathrm{mW} / \mathrm{g})\end{array}$ & $\begin{array}{c}t \\
(\mathrm{~h})\end{array}$ & $\begin{array}{l}\text { Heat fl. } \\
(\mathrm{mW} / \mathrm{g})\end{array}$ & $\mathrm{t}(\mathrm{h})$ & $\begin{array}{l}\text { Heat fl. } \\
(\mathrm{mW} / \mathrm{g})\end{array}$ & $\mathrm{t}(\mathrm{h})$ & $\begin{array}{l}\text { Heat fl. } \\
(\mathrm{mW} / \mathrm{g})\end{array}$ \\
\hline $\mathrm{C}_{3} \mathrm{~A}$ & 180 & - & - & - & - & - & - & - & - \\
\hline $\mathrm{C}_{3} \mathrm{~A}+$ ter & 120 & - & - & - & - & - & - & - & - \\
\hline $\mathrm{C}_{12} \mathrm{~A}_{7}$ & 159 & 1 & 20 & 5.5 & 9.0 & 8.5 & 13 & - & - \\
\hline $\mathrm{C}_{12} \mathrm{~A}_{7}+$ ter & 134 & 1 & 8.9 & 3 & 6.3 & 5 & 10 & 13.5 & 1.8 \\
\hline $\mathrm{CA}$ & 99 & - & - & 2.5 & 0.39 & 21 & 27 & 12 & 1 \\
\hline $\mathrm{CA}+$ ter & 121 & - & - & 2 & 0.39 & 4.5 & 24 & 17 & 0.8 \\
\hline $\mathrm{C}_{4} \mathrm{~A}_{3} \overline{\mathrm{S}}$ & 71 & - & - & 2.8 & 0.33 & 7 & 114 & - & - \\
\hline $\mathrm{C}_{4} \mathrm{~A}_{3} \overline{\mathrm{S}}+$ ter & 23 & 1 & 1.3 & 2 & 1 & 4 & 28 & 9.5 & 1.1 \\
\hline Ternesite & 117 & - & - & - & - & - & - & - & - \\
\hline
\end{tabular}

661

662 


\begin{tabular}{|c|c|c|}
\cline { 2 - 3 } \multicolumn{1}{c|}{} & Experimental total heat & $\Delta \mathrm{Q}$ \\
\hline Ternesite & $43 \mathrm{~J} / \mathrm{g}$ & \\
\hline CA & $563 \mathrm{~J} / \mathrm{g}$ & $91 \%$ \\
\hline $\mathrm{CA}+$ Ternesite & $1076 \mathrm{~J} / \mathrm{g}$ & \\
\hline $\mathrm{C}_{12} \mathrm{~A}_{7}$ & $557 \mathrm{~J} / \mathrm{g}$ & $87 \%$ \\
\hline $\mathrm{C}_{12} \mathrm{~A}_{7}+$ Ternesite & $1043 \mathrm{~J} / \mathrm{g}$ & \\
\hline $\mathrm{C}_{4} \mathrm{~A}_{3} \overline{\mathrm{S}}$ & $464 \mathrm{~J} / \mathrm{g}$ & $36 \%$ \\
\hline $\mathrm{C}_{4} \mathrm{~A}_{3} \overline{\mathrm{S}}+$ Ternesite & $630 \mathrm{~J} / \mathrm{g}$ & \\
\hline $\mathrm{C}_{3} \mathrm{~A}$ & $744 \mathrm{~J} / \mathrm{g}$ & $19 \%$ \\
\hline $\mathrm{C}_{3} \mathrm{~A}+$ Ternesite & $885 \mathrm{~J} / \mathrm{g}$ & \\
\hline
\end{tabular}

665

666

667

Table 5. Quantitative mineralogical analysis of blended aluminate + ternesite pastes

668

\begin{tabular}{|c|c|c|c|c|c|c|c|c|c|c|}
\cline { 2 - 11 } \multicolumn{1}{c|}{} & $\mathrm{C}_{5} \mathrm{~S}_{2} \overline{\mathrm{S}}$ & $\mathrm{C}_{2} \mathrm{~S}$ & $\mathrm{C}_{3} \mathrm{~A}$ & $\mathrm{C}_{4} \mathrm{~A}_{3} \overline{\mathrm{S}}$ & $\mathrm{C}_{2} \mathrm{ASH}_{8}$ & $\mathrm{AFm}$ & $\mathrm{C}_{3} \mathrm{AH}_{6}$ & $\mathrm{Hc}$ & $\begin{array}{c}\% \\
\text { amorphous }\end{array}$ & $\mathrm{Rwp}$ \\
\hline $\mathrm{C}_{3} \mathrm{~A}+\mathrm{C}_{5} \mathrm{~S}_{2} \overline{\mathrm{S}}$ & 43,11 & 1.71 & 0.72 & & & 1.76 & 5.36 & 6.91 & 40.42 & 11.31 \\
\hline $\mathrm{C}_{12} \mathrm{~A}_{7+} \mathrm{C}_{5} \mathrm{~S}_{2} \overline{\mathrm{S}}$ & 22.62 & 2.70 & & & 24.84 & 11.61 & & & 38.23 & 11.20 \\
\hline $\mathrm{C}_{4} \mathrm{~A}_{3} \overline{\mathrm{S}}+\mathrm{C}_{5} \mathrm{~S}_{2} \overline{\mathrm{S}}$ & 50.51 & 1.66 & & 0.99 & & 10.63 & & 1.11 & 35.1 & 8.80 \\
\hline $\mathrm{CA}+\mathrm{C}_{5} \mathrm{~S}_{2} \overline{\mathrm{S}}$ & 23.29 & 2.21 & & & 35.95 & 5.84 & & & 32.71 & 11.62 \\
\hline ICSD card & 85123 & 81096 & 1841 & 80361 & 69413 & 100138 & 202316 & 263124 & & \\
\hline
\end{tabular}


671 Table 6. Absorption bands on FTIR spectra for $7 \mathrm{~d}\left(25^{\circ} \mathrm{C}\right)$ pastes. $\mathrm{s}=$ Strong, vs=very strong, $\mathrm{w}=$ weak, $\mathrm{vw}=$ very weak

\begin{tabular}{|c|c|c|c|c|}
\hline Paste $\mathrm{C}_{3} \mathrm{~A}$ & Paste $\mathrm{C}_{4} \mathrm{~A}_{3} \overline{\mathrm{S}}$ & Paste CA & Paste $\mathrm{C}_{12} \mathrm{~A}_{7}$ & Attributed to \\
\hline & & 3682 & 3682 & \\
\hline & $3676 \mathrm{vw}$ & & & $\mathrm{AFm} / \mathrm{Hc}$ \\
\hline \multirow[t]{2}{*}{$3660 \mathrm{~s}$} & & & & $\mathrm{C}_{3} \mathrm{AH}_{6}$ \\
\hline & $3620 \mathrm{w}$ & 3620 & 3620 & $\mathrm{AH}_{3}$ \\
\hline \multirow[t]{2}{*}{$3543 \mathrm{vw}$} & & & & $\mathrm{C}_{3} \mathrm{AH}_{6}$ \\
\hline & $3526 \mathrm{w}$ & 3526 & 3526 & $\mathrm{AH}_{3}$ \\
\hline \multicolumn{5}{|l|}{$3523 \mathrm{vw}$} \\
\hline & $3467 \mathrm{w}$ & 3467 & 3467 & $\mathrm{AH}_{3} / \mathrm{C}_{2} \mathrm{AH}_{8}$ \\
\hline & $1167 \mathrm{w}$ & & & AFm \\
\hline & $1115-1108 \mathrm{~s}$ & & & AFm \\
\hline & $1024 \mathrm{~s}$ & 1024 & 1024 & $\mathrm{AH}_{3}$ \\
\hline & $968 \mathrm{w}$ & 968 & & $\mathrm{AH}_{3}$ \\
\hline $899 \mathrm{w}$ & & & & $\mathrm{C}_{3} \mathrm{~A}$ \\
\hline $865 \mathrm{w}$ & & 865 & 865 & $\mathrm{C}_{3} \mathrm{~A} / \mathrm{CAH}_{10} / \mathrm{C}_{2} \mathrm{AH}_{8}$ \\
\hline \multirow[t]{7}{*}{$809 \mathrm{~s}$} & & & & $\mathrm{C}_{3} \mathrm{AH}_{6} / \mathrm{C}_{3} \mathrm{~A}$ \\
\hline & $786 \mathrm{~s}$ & & & AFm \\
\hline & & 777 & 777 & \\
\hline & & 710 & 710 & $\mathrm{C}_{2} \mathrm{AH}_{8}$ \\
\hline & & 636 & & \\
\hline & $617 \mathrm{w}$ & & & \\
\hline & & 578 & 578 & $\mathrm{CAH}_{10}$ \\
\hline \multirow[t]{2}{*}{$521 \mathrm{~s}$} & 528 vs & 528 & 528 & $\begin{array}{l}\mathrm{CAH}_{10} / \mathrm{C}_{3} \mathrm{~A} \\
\mathrm{C}_{2} \mathrm{AH}_{8} / \mathrm{AFm}\end{array}$ \\
\hline & $422 \mathrm{~s}$ & 422 & 422 & $\mathrm{CAH}_{10} / \mathrm{C}_{2} \mathrm{AH}_{8} / \mathrm{AFm}$ \\
\hline
\end{tabular}

673

674

675

676

677

\begin{tabular}{|c|c|c|c|c|c|c|c|c|}
\hline Reference & Year & $\mathrm{CAH}_{10}$ & $\mathrm{C}_{2} \mathrm{AH}_{8}$ & $\mathrm{C}_{3} \mathrm{AH}_{6}$ & $\mathrm{AH}_{3}$ & $\mathrm{C}_{2} \mathrm{ASH}_{8}$ & $\mathrm{AFm}$ & Hc y Mc \\
\hline [27] & 1992 & $100-160$ & $140-200$ & $290-350$ & 230,300 & $190-230$ & & \\
\hline [28] & 1983 & $\sim 140$ & $\sim 170$ & $\sim 300$ & $\sim 280$ & & & \\
\hline [29] & 2000 & $110-160$ & 170,270 & 289,450 & 181,3 & & & $\mathbf{8 6}, 155,220$ \\
\hline [30] & 2007 & & $88, \mathbf{1 1 0}, \mathbf{1 7 5}, \mathbf{2 9 5}$ & & & & & \\
\hline [31] & 1988 & & $145-150,265-280$ & 300 & & & & 160 \\
\hline [32] & 1978 & $\sim 125$ & & $\sim 330$ & $\sim 290$ & & & \\
\hline [33] & 2013 & 165 & 285 & $285-451$ & $\sim 260-290$ & & & \\
\hline [34] & 2009 & $\sim 100-170$ & $\sim 110-290$ & 330 & $\sim 300-470$ & $120-185$ & & \\
\hline$[35]$ & 2003 & & $240-285$ & $290-300$ & $260-270$ & & $180-200$ & \\
\hline [36] & 1976 & & & & & $120, \mathbf{1 6 5}, \mathbf{2 2 0}, \mathbf{4 3 0}$ & & \\
\hline [37] & 2016 & & & & & & $190-200,270-290$ & \\
\hline$[38]$ & 2012 & & & $\mathbf{2 7 3}, 400$ & & & $120-170$ & 150 \\
\hline This work & 2017 & & $\mathbf{9 2 , 1 5 0 , 3 1 1}$ & $\mathbf{3 0 3}, 425$ & $239, \mathbf{3 0 0 , 5 1 5}$ & & $120,180,295$ & \\
\hline
\end{tabular}

678

679

Table 7. Temperatures and temperature ranges on DTA curves for phases obtained during hydration $\left({ }^{\circ} \mathrm{C}\right)$ 
680

681

682

683

684

685

686

687

688

689

690

691

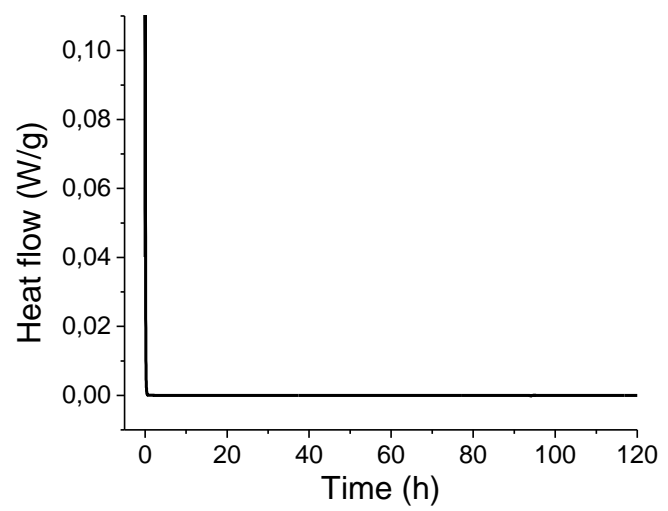

Table 8. Amount of hydrates determined by XRD and under hypothesis of all sulphate in solution giving AFm and all aluminium in excess forming strätlingite. Their corresponding lost of water. TG lost of mass

\begin{tabular}{|c|c|c|c|c|c|}
\hline wt(\%) & AFm & $\mathrm{C}_{2} \mathrm{ASH}_{8}$ & $\mathrm{AH}_{3}$ & $\begin{array}{c}\text { Lost of mass } \\
\text { (water) }\end{array}$ & $\begin{array}{c}\mathrm{P} \\
\left(1000^{\circ} \mathrm{C}\right)\end{array}$ \\
\hline & DRX/hip & DRX/hip & DRX/hip & DRX/hip & TG \\
\hline $\mathrm{C}_{12} \mathrm{~A}_{7}+\mathrm{C}_{5} \mathrm{~S}_{2} \overline{\mathrm{S}}$ & $11.6 / 34$ & $24.8 / 17.1$ & --- & $11.5 / 17.7$ & 22 \\
\hline $\mathrm{CA}+\mathrm{C}_{5} \mathrm{~S}_{2} \overline{\mathrm{S}}$ & $5.8 / 30.4$ & $36 / 40.9$ & --- & $12.8 / 21.1$ & 25.3 \\
\hline $\mathrm{C}_{4} \mathrm{~A}_{3} \overline{\mathrm{S}}+\mathrm{C}_{5} \mathrm{~S}_{2} \overline{\mathrm{S}}$ & $10.6 / 29.3$ & --- & $-/ 14$ & $4.1 / 15.3$ & 17.6 \\
\hline
\end{tabular}
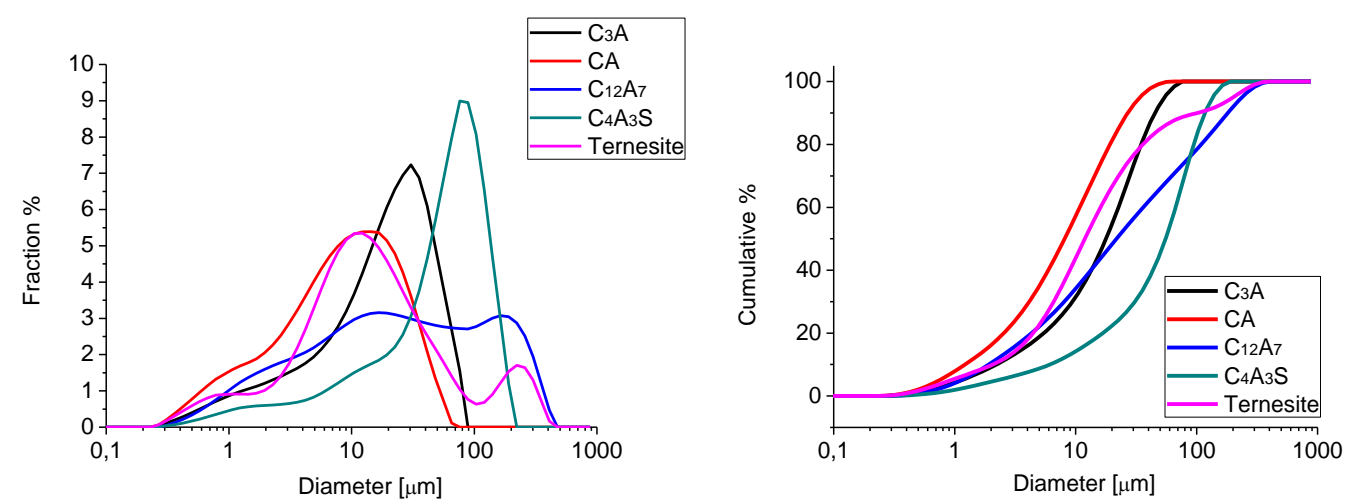

Figure 1. Particle size distribution (PSD) and the derivative of the PSD of samples $\mathrm{C}_{3} \mathrm{~A}$, $\mathrm{CA}, \mathrm{C}_{12} \mathrm{~A}_{7}, \mathrm{C}_{4} \mathrm{~A}_{3} \overline{\mathrm{s}}$, and ternesite.
692

693

694

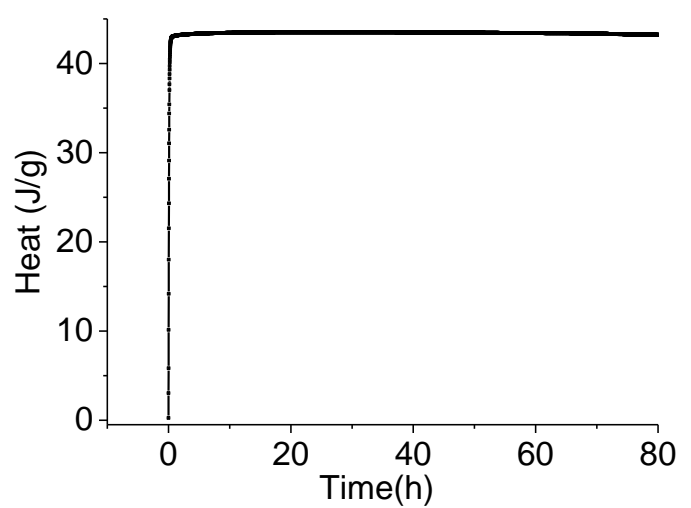

Figure 2. Heat flow and heat curves for 7 day $\left(25^{\circ} \mathrm{C}\right)$ ternesite hydration 


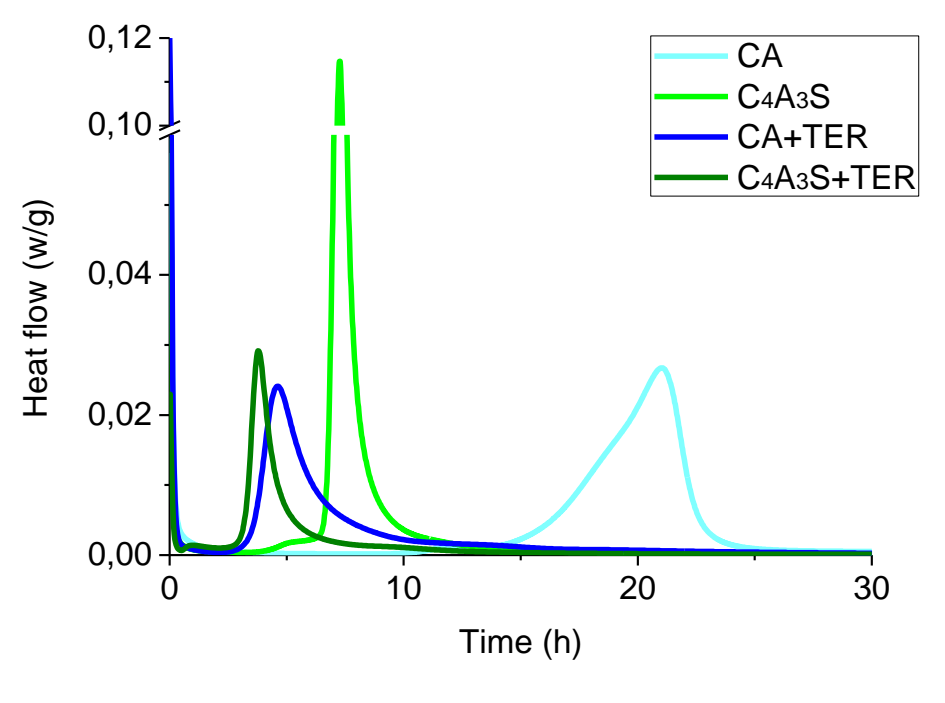

695

696

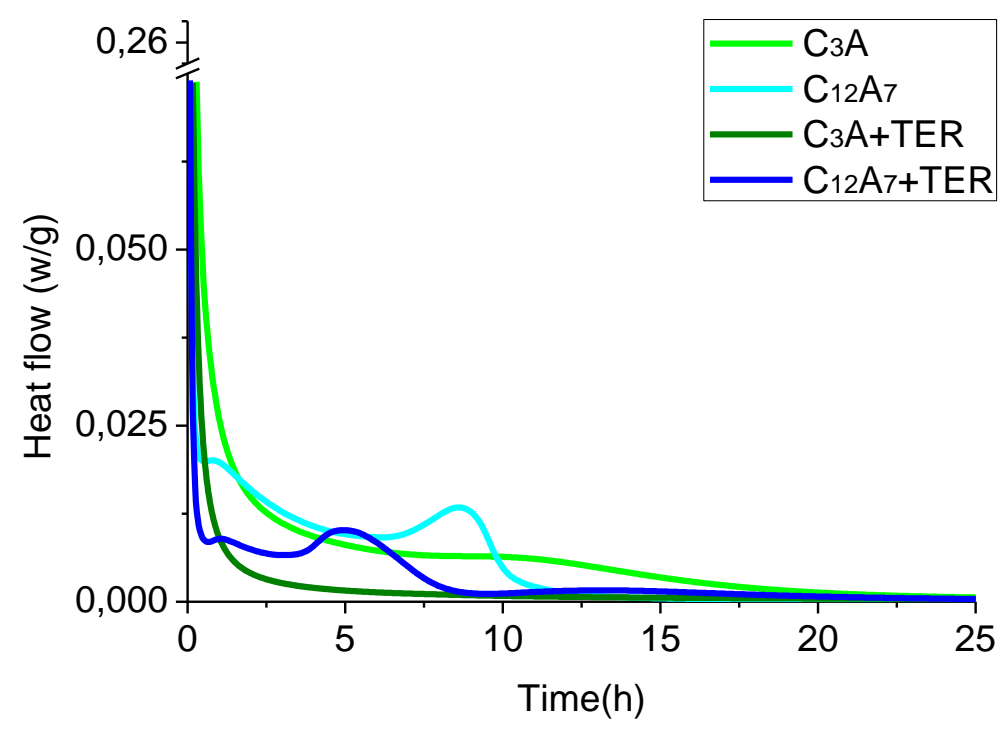

697

b)

Time(h)

698

Figure 3. Heat flow curves for synthesised aluminates and their ternesite blends pastes at $25{ }^{\circ} \mathrm{C}$

700

701 


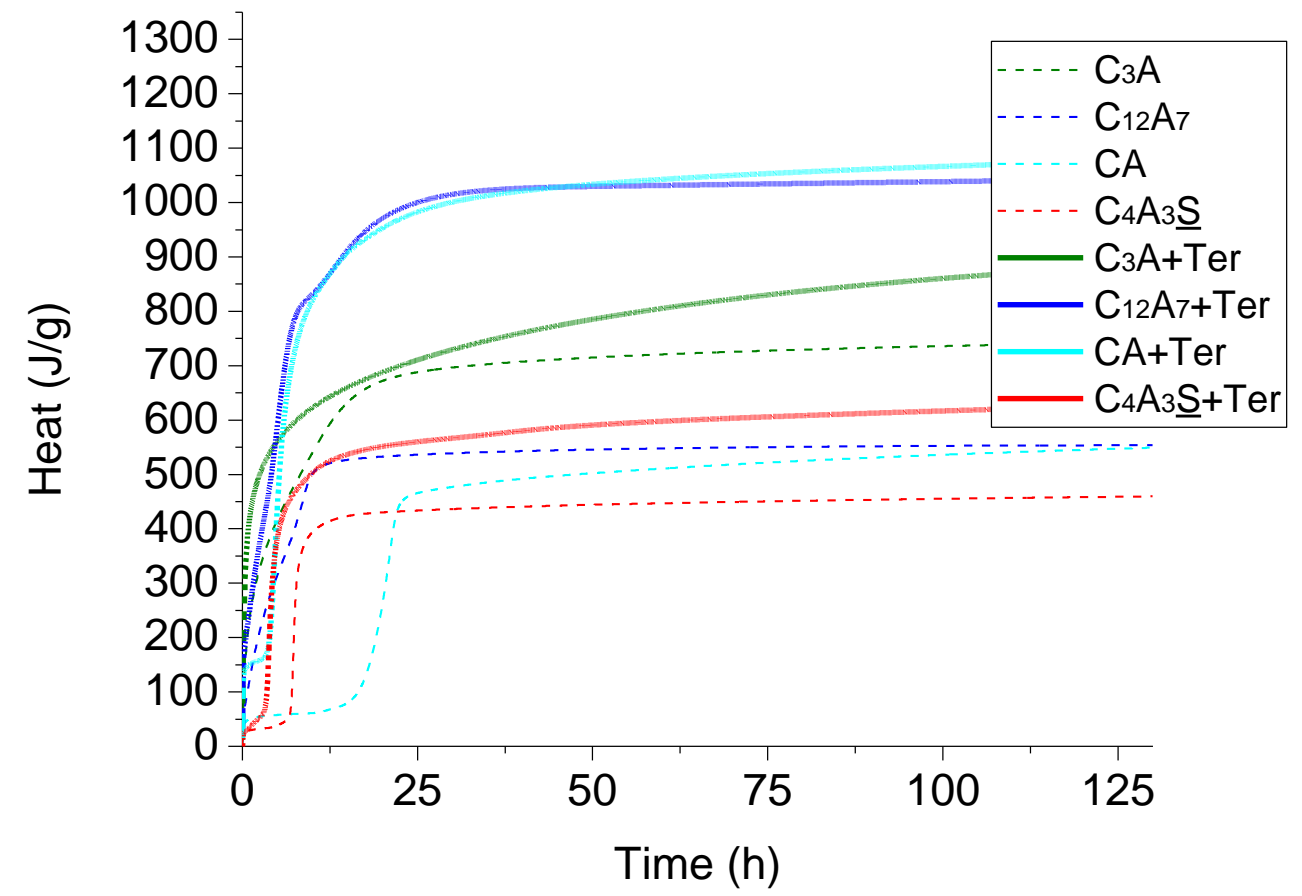

705

706

707

708

709

710
Figure 4. Heat of hydration curves for $7 \mathrm{~d}\left(25^{\circ} \mathrm{C}\right)$ hydrated aluminates and their ternesite blends (per unit of mass of aluminate) 


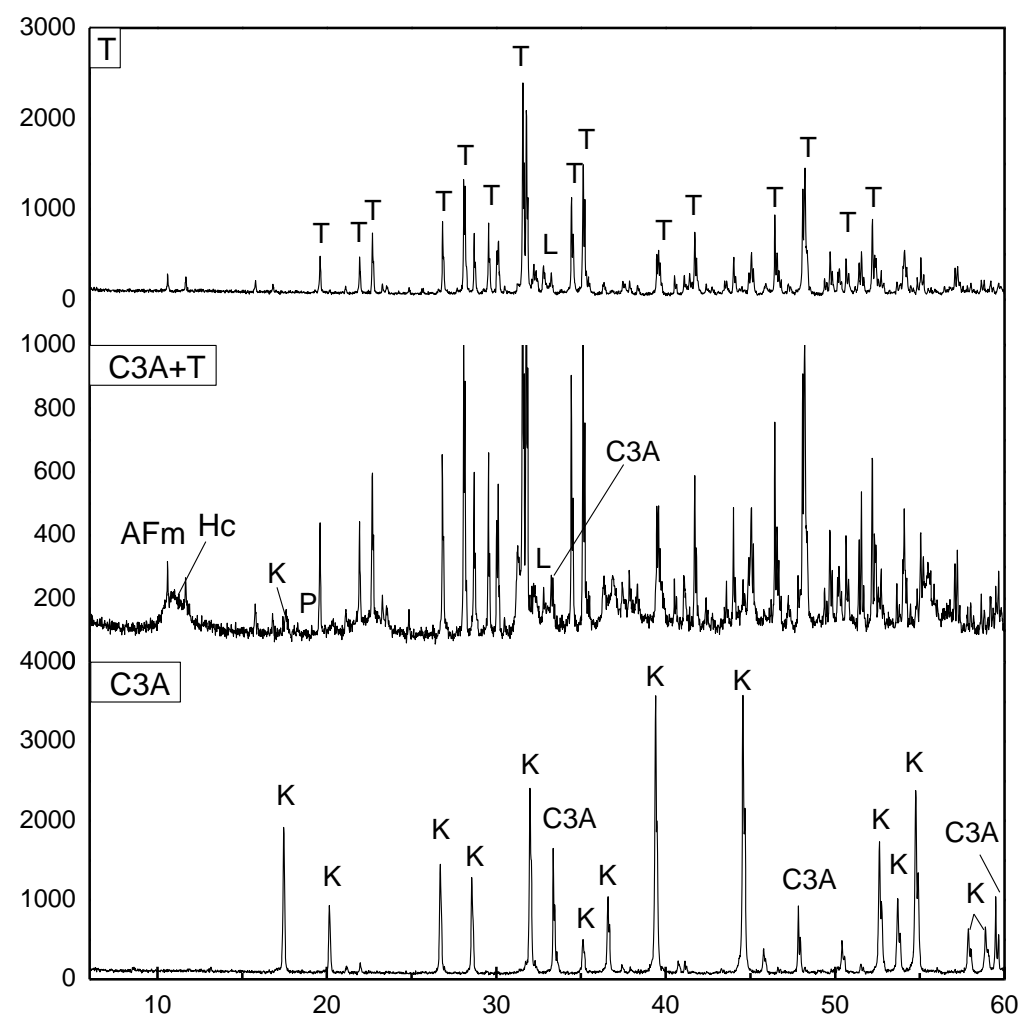

711

712

713

714

715

716
Figure 5. Diffractograms for $7 \mathrm{~d}\left(25^{\circ} \mathrm{C}\right) \mathrm{C}_{3} \mathrm{~A}$ and $\mathrm{C}_{3} \mathrm{~A} / \mathrm{C}_{5} \mathrm{~S}_{2} \overline{\mathrm{S}}(1: 2)$ pastes: $\mathrm{K}=$ katoite; $\mathrm{AFm}=$ Calcium sulfoaluminate $\mathrm{L}=$ larnite; $\mathrm{T}=$ ternesite; $\mathrm{Hc}=$ calcium hemicarboaluminate; $\mathrm{P}=$ portlandite 


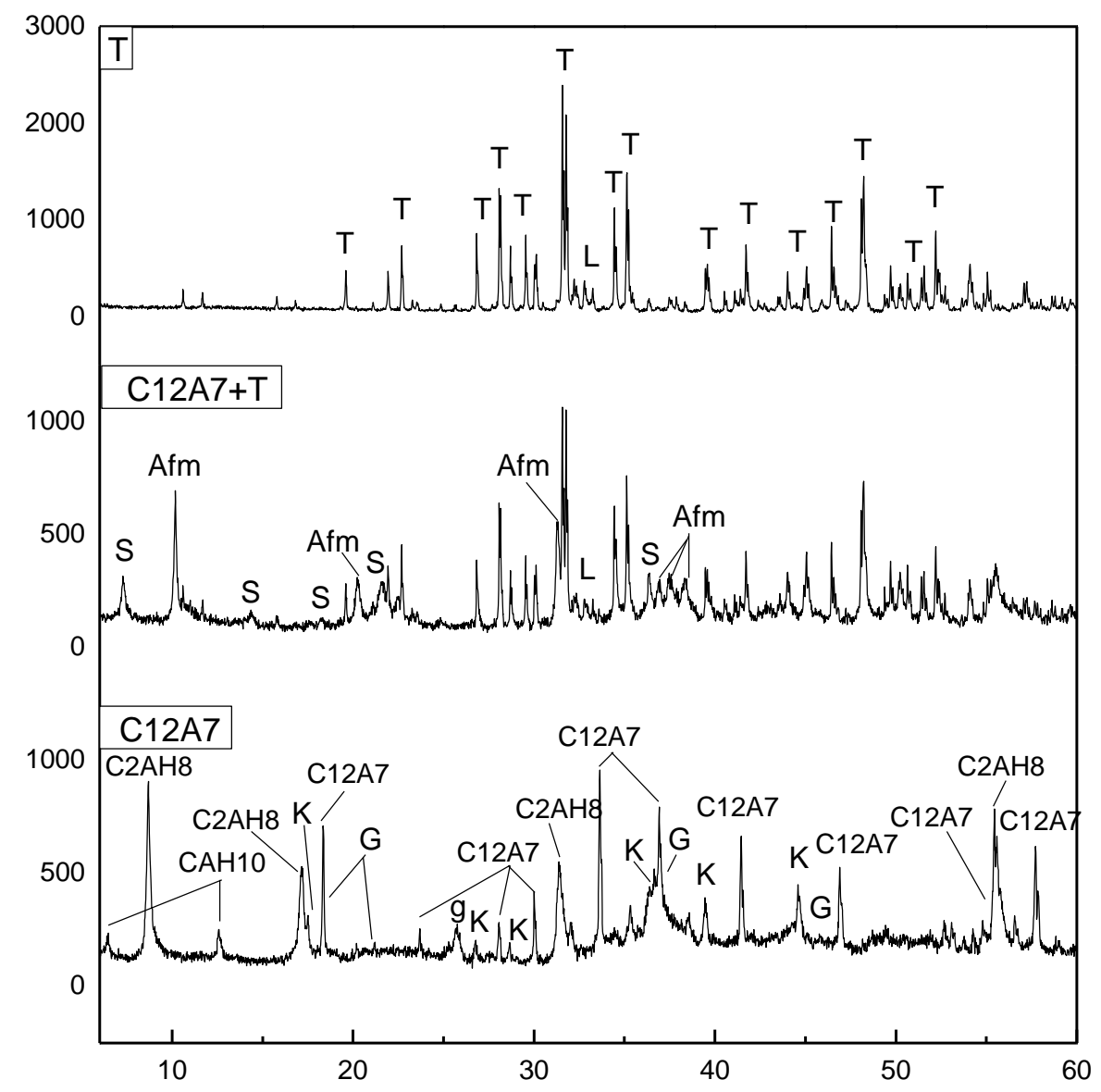

Figure 6. Diffractograms for $7 \mathrm{~d}\left(25^{\circ} \mathrm{C}\right) \mathrm{C}_{12} \mathrm{~A}_{7}$ and $\mathrm{C}_{12} \mathrm{~A}_{7} / \mathrm{C}_{5} \mathrm{~S}_{2} \overline{\mathrm{S}}(1: 2)$ pastes: $\mathrm{K}=$ katoite; $\mathrm{G}=$ gibbsite; $\mathrm{L}=$ larnite; $\mathrm{S}=$ strätlingite; $\mathrm{T}=$ ternesite; $\mathrm{Afm}=$ calcium monosulfoaluminate hydrate; $\mathrm{g}=$ grossite 


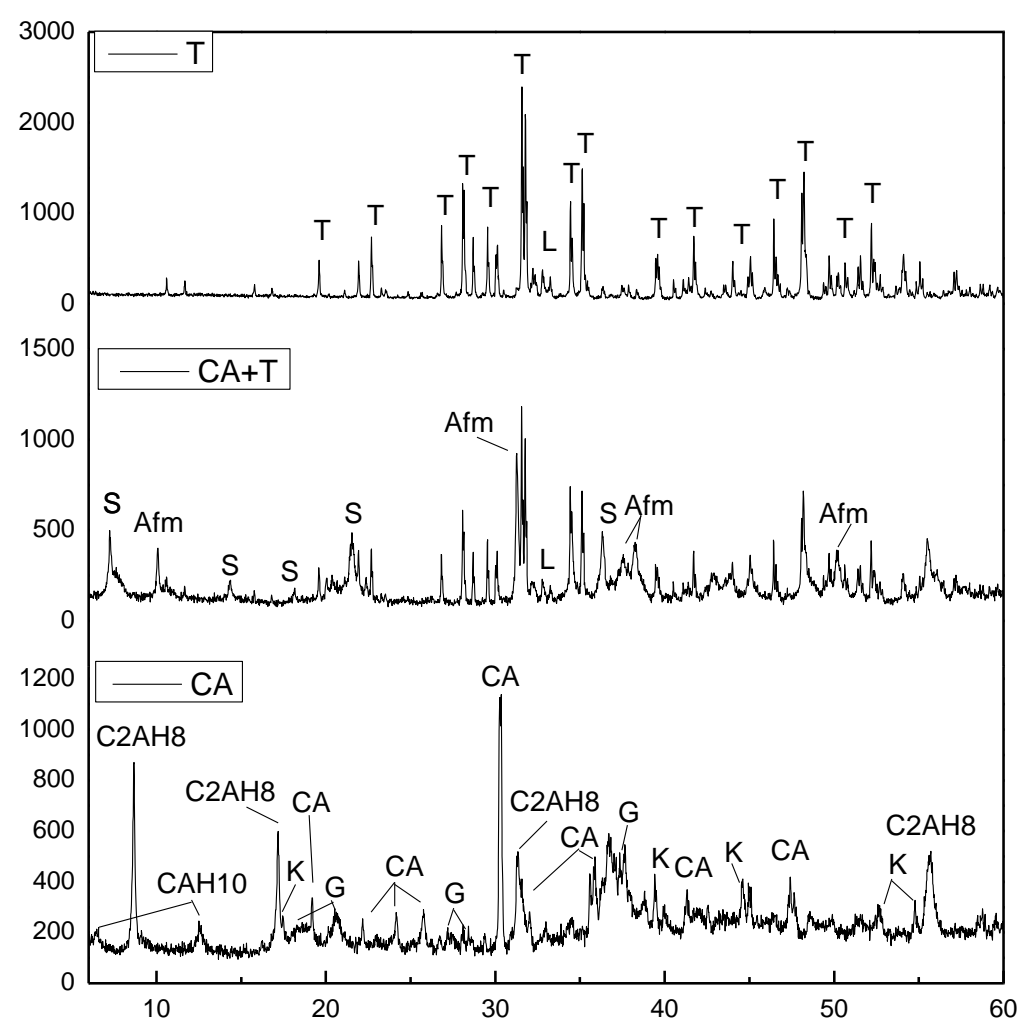

724

725

726

727

728

729
Figure 7. Diffractograms for $7 \mathrm{~d}\left(25^{\circ} \mathrm{C}\right) \mathrm{CA}$ and $\mathrm{CA} / \mathrm{C}_{5} \mathrm{~S}_{2} \hat{\mathrm{s}}(1: 2)$ pastes: $\mathrm{K}=$ katoite; $\mathrm{G}=$ gibbsite; $\mathrm{L}=$ larnite; $\mathrm{T}=$ ternesite; Afm = calcium monosulfoaluminate hydrate; $\mathrm{S}=$ strätlingite 


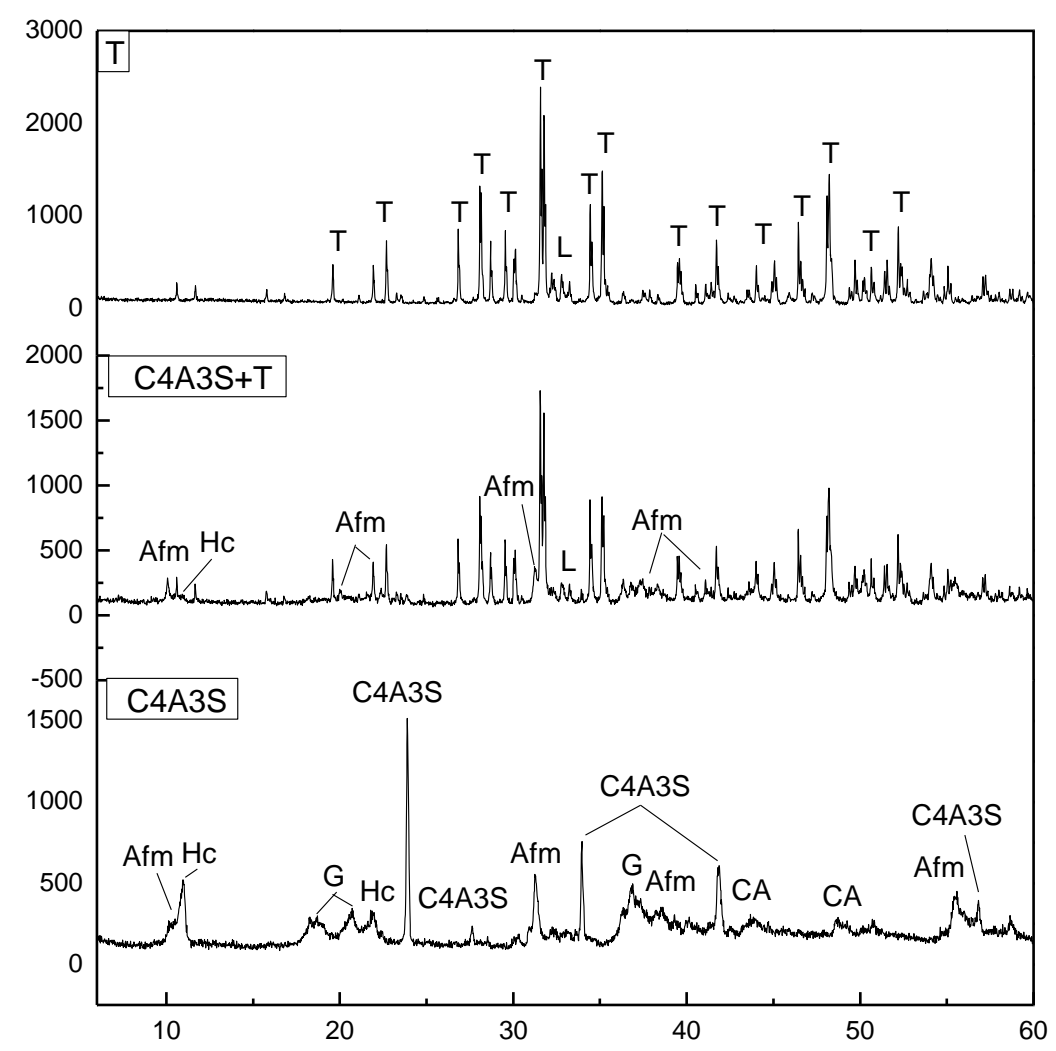

Figure 8. Diffractograms for $7 \mathrm{~d}\left(25^{\circ} \mathrm{C}\right) \mathrm{C}_{4} \mathrm{~A}_{3} \overline{\mathrm{S}}$ and $\mathrm{C}_{4} \mathrm{~A}_{3} \overline{\mathrm{S}} / \mathrm{C}_{5} \mathrm{~S}_{2} \overline{\mathrm{S}}$ (1:2) pastes: = gibbsite; $\mathrm{L}=$ larnite; $\mathrm{T}=$ ternesite; $\mathrm{Afm}=$ calcium monosulfoaluminate hydrate; $\mathrm{Hc}=$ calcium monocarboaluminate hydrate 


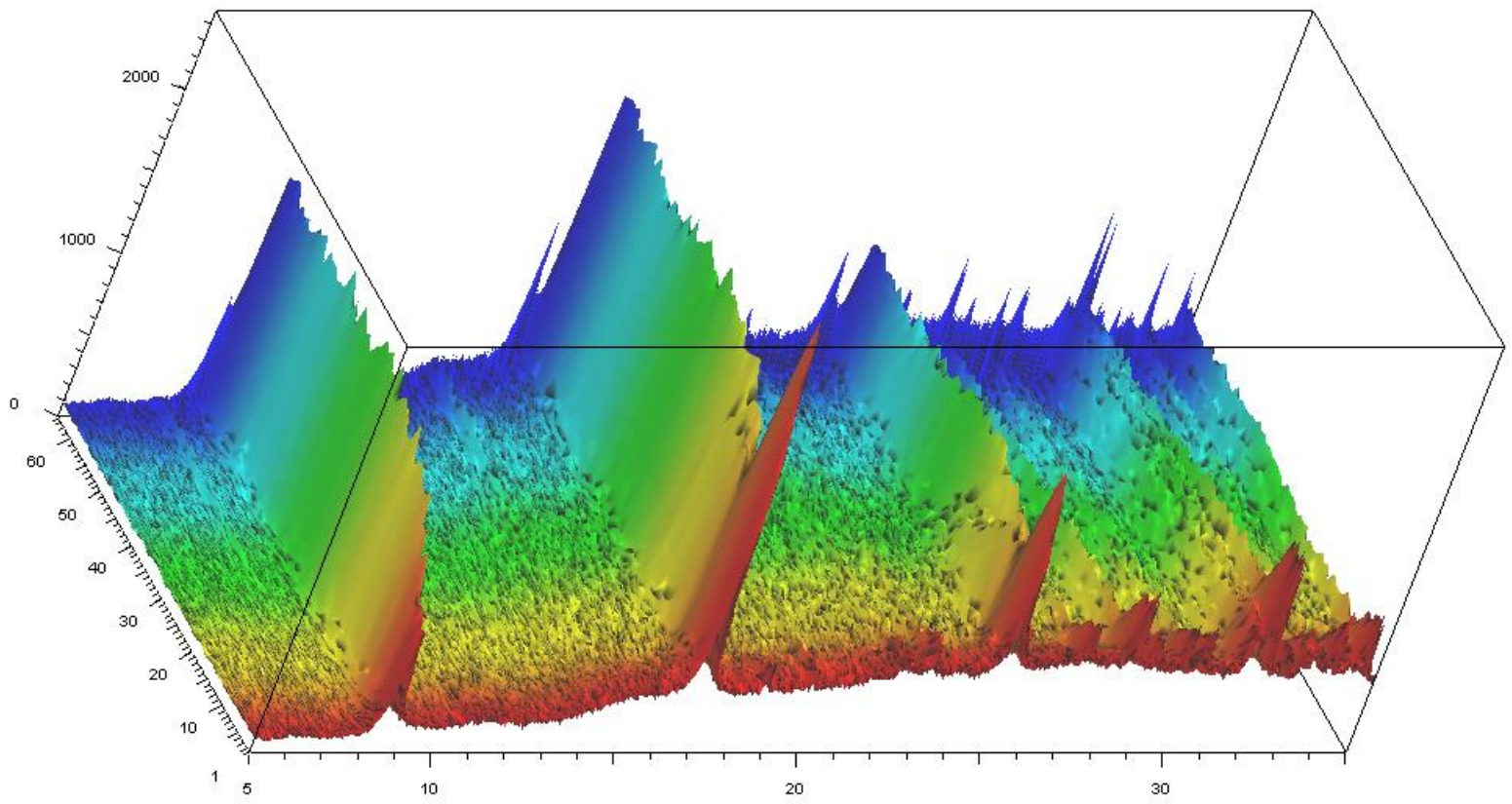

a) $1-64$

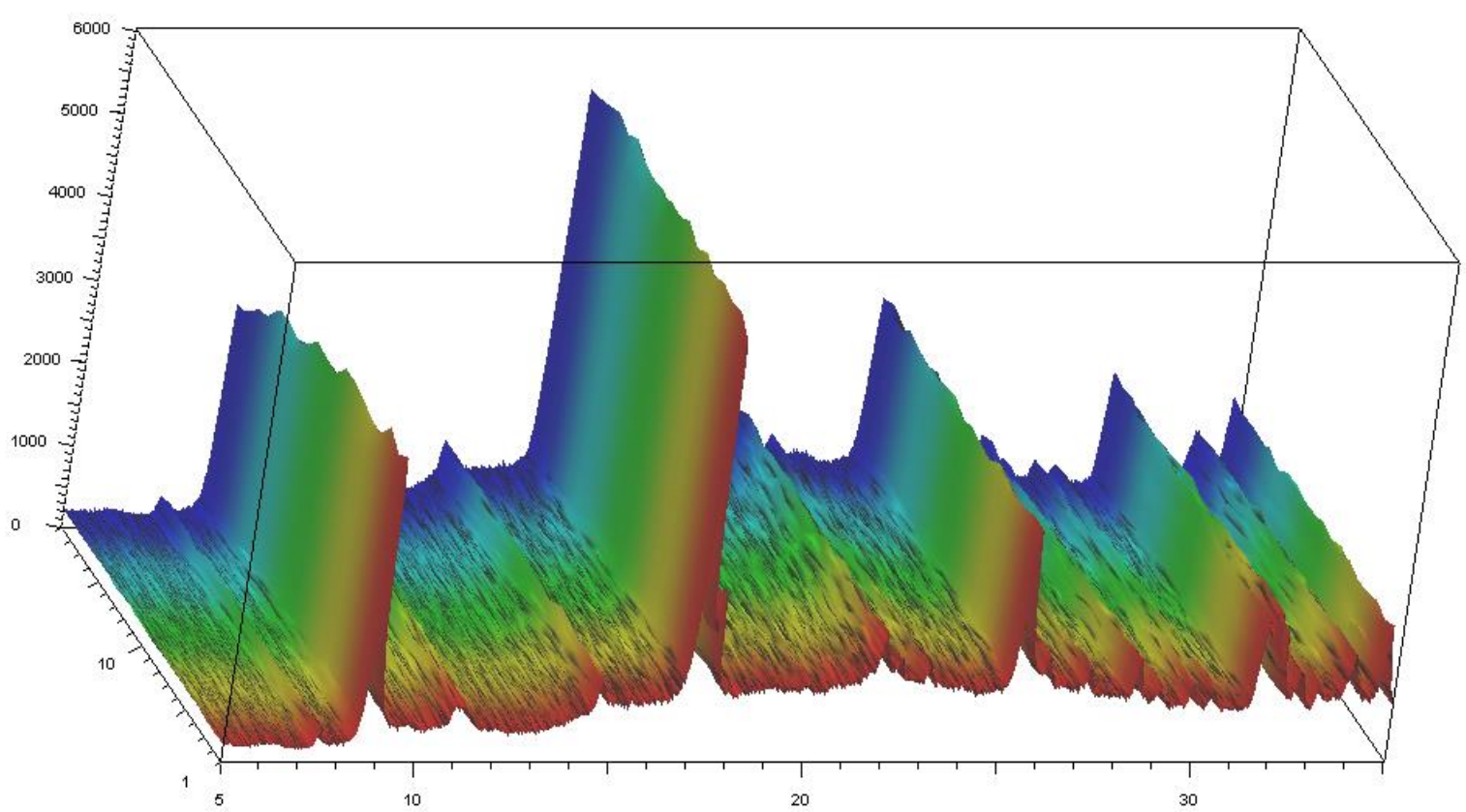

b) $65-84$

Figure 9. Three-dimensional diffractograms for $0 \mathrm{~h}-20 \mathrm{~h} \mathrm{C}_{12} \mathrm{~A}_{7}+$ ternesite pastes: a) samples 1-64 (0-12 h); b) samples 65-84 (12-20 h) 


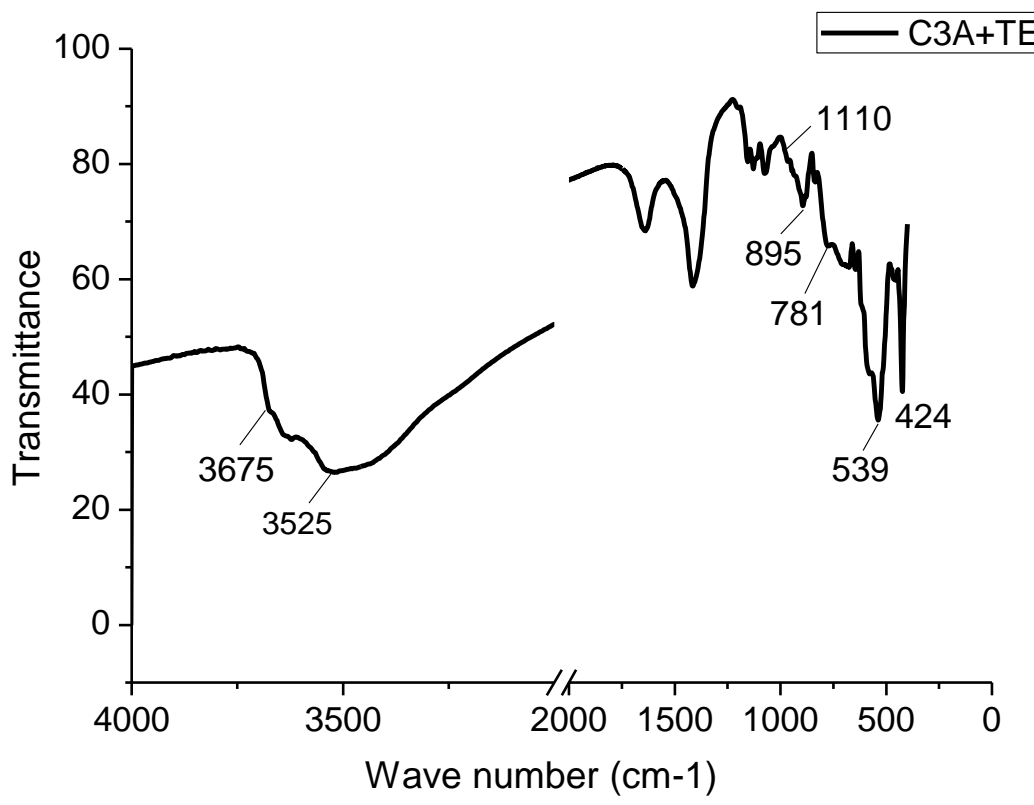

749

Figure 10. FTIR spectra for $7 \mathrm{~d}\left(25^{\circ} \mathrm{C}\right) \mathrm{C}_{3} \mathrm{~A}+$ ternesite paste after subtracting the ternesite spectrum

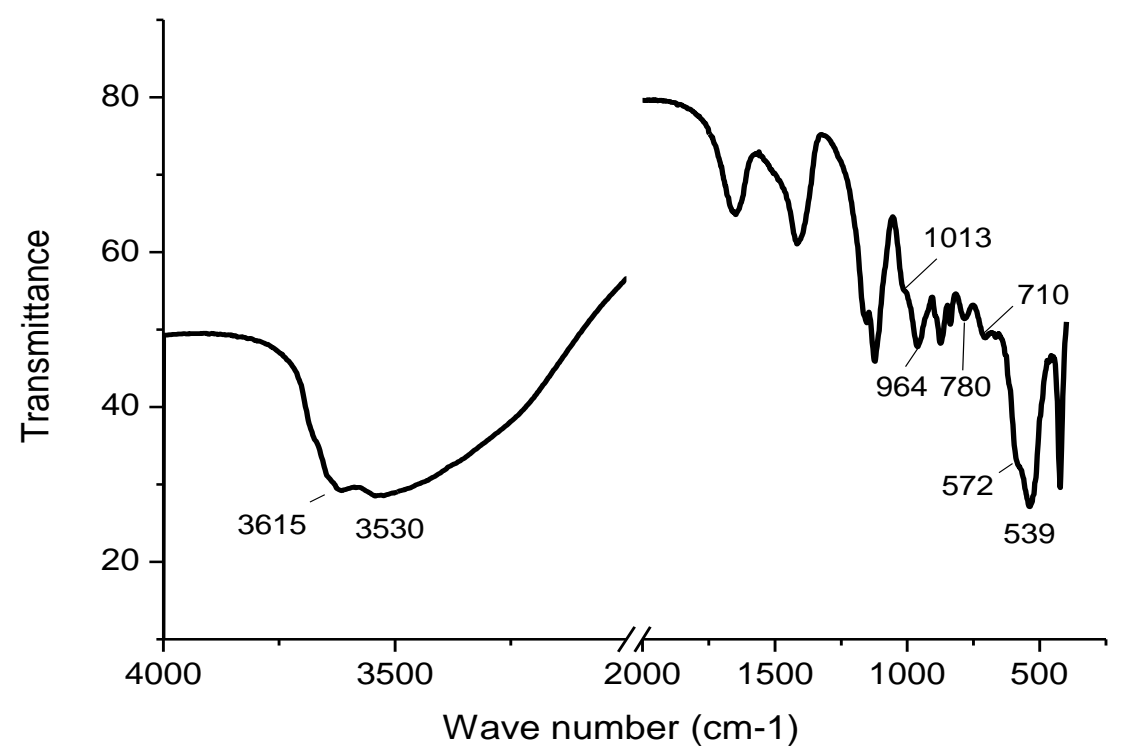

Figure 11. FTIR spectra for $7 \mathrm{~d}\left(25^{\circ} \mathrm{C}\right) \mathrm{C}_{12} \mathrm{~A}_{7}+$ ternesite paste after subtracting the ternesite spectrum

753

754 


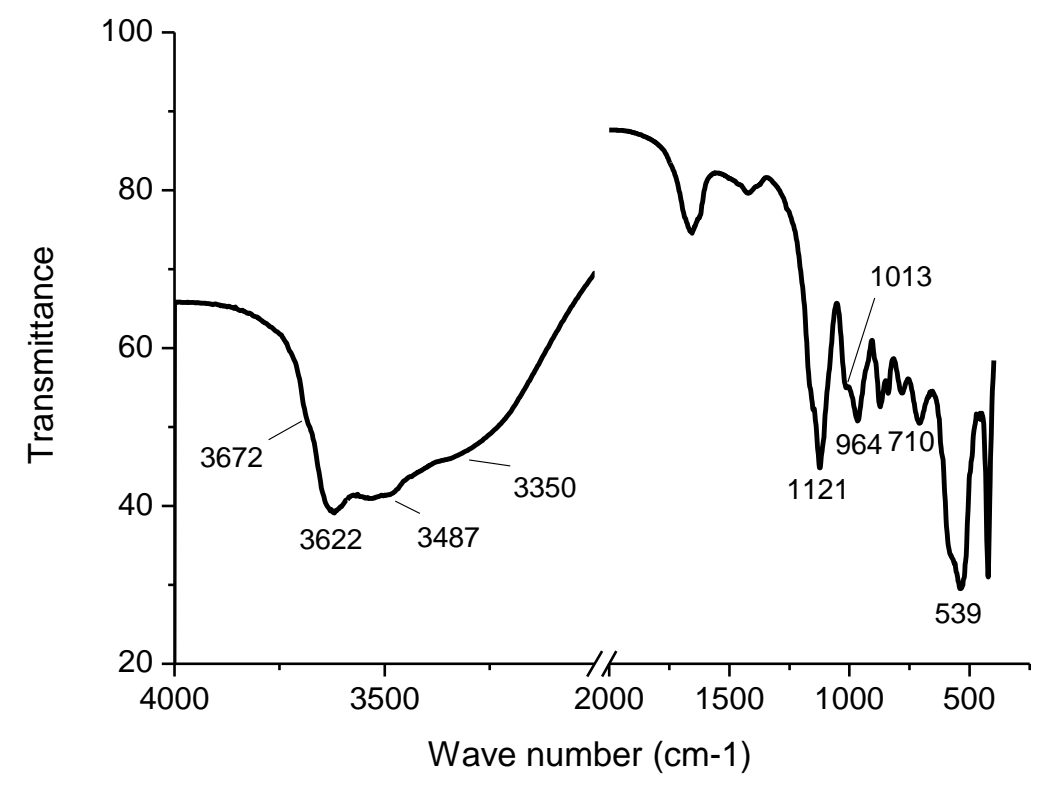

755

756 Figure 12. FTIR spectra for $7 \mathrm{~d}\left(25^{\circ} \mathrm{C}\right) \mathrm{CA}+$ ternesite paste after subtracting the ternesite 757 spectrum

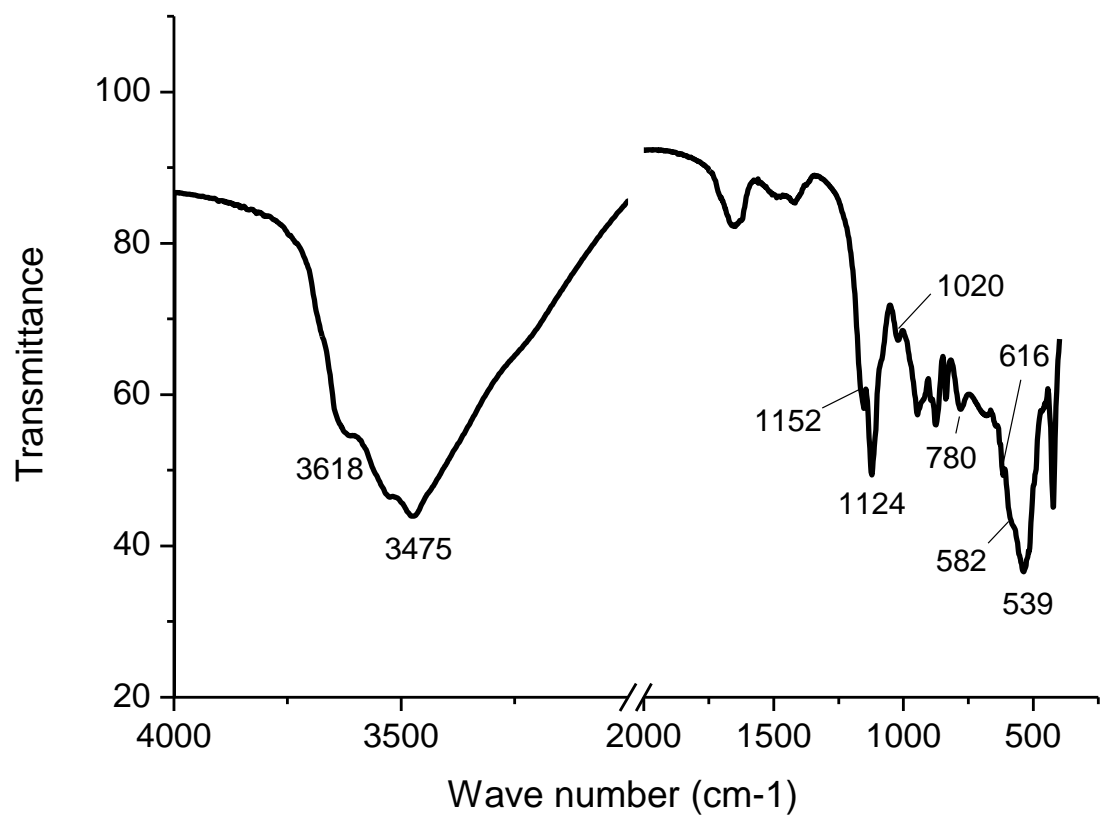

Figure 13. FTIR spectra for $7 \mathrm{~d}\left(25^{\circ} \mathrm{C}\right) \mathrm{C}_{4} \mathrm{~A}_{3} \overline{\mathrm{S}}+$ ternesite paste after subtracting the ternesite spectrum 
764

765

766

767

768

769

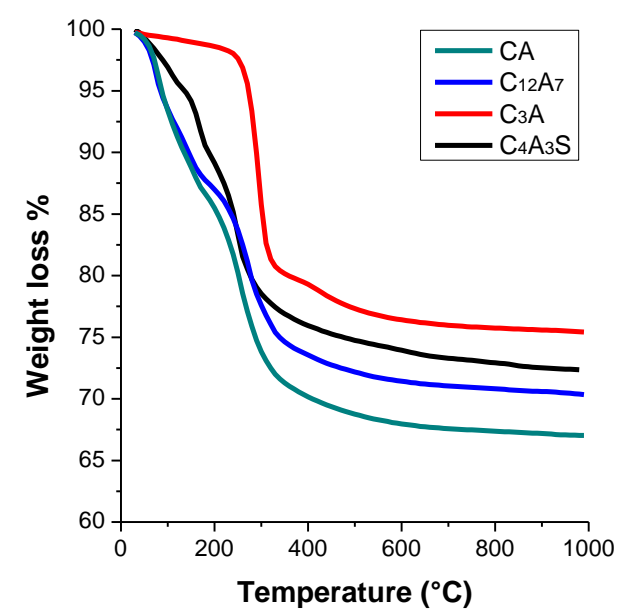

a)

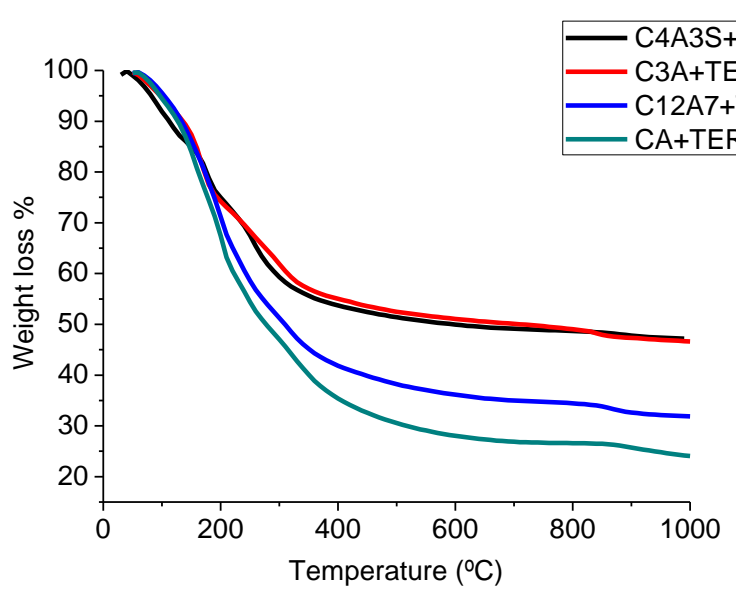

b)

Figure 14. a) Weight loss in aluminate pastes; b) weight loss in aluminate+ternesite pastes (per g of aluminate)

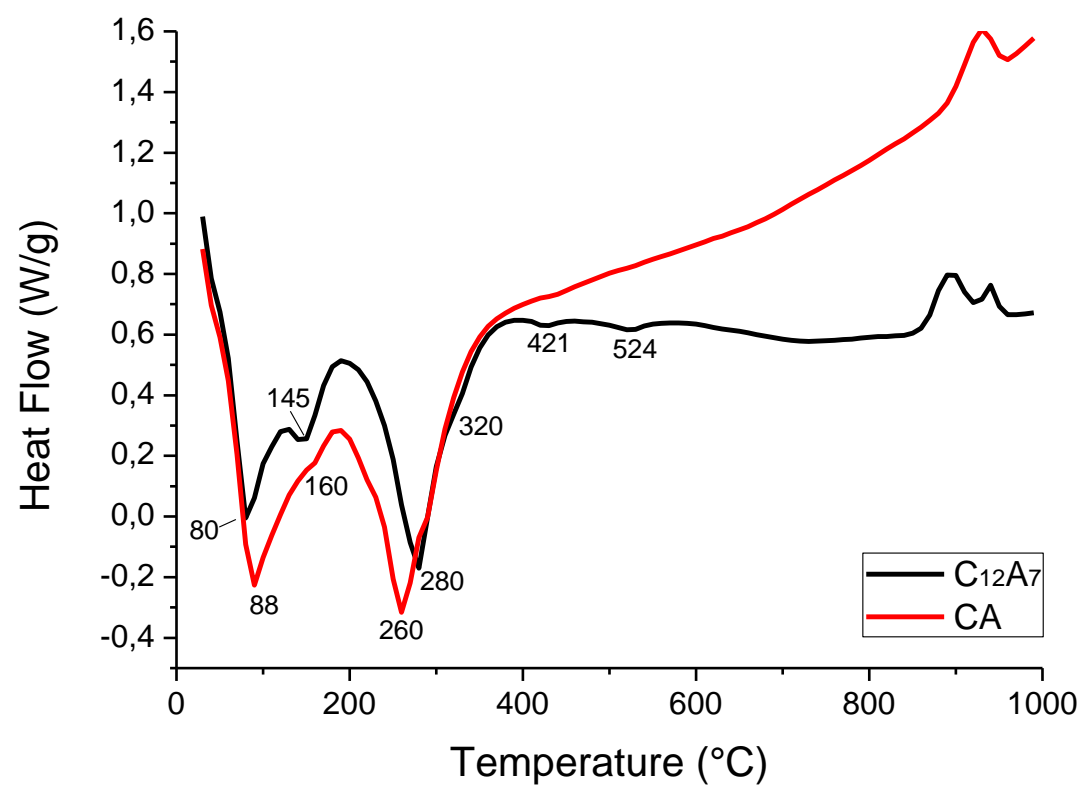

Figure 15. DTA curves for pastes $\mathrm{CA}$ and $\mathrm{C}_{12} \mathrm{~A}_{7}$ 


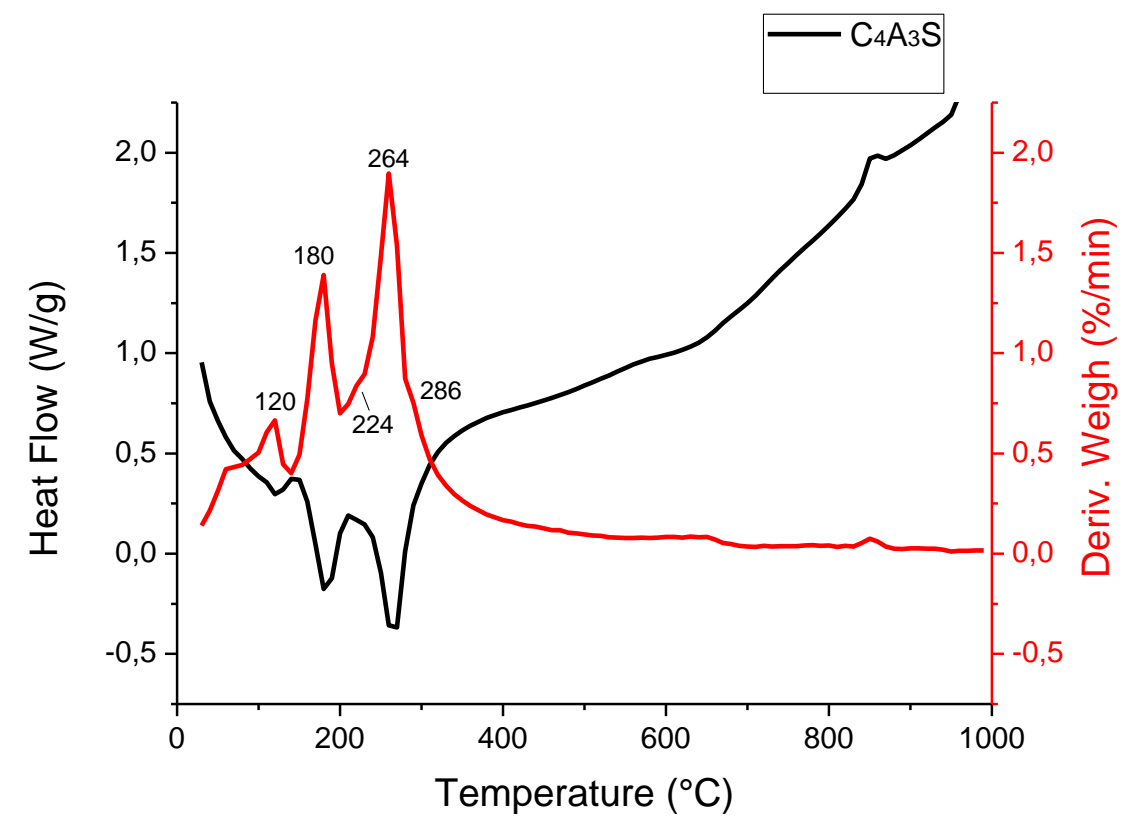

777

Figure 16.DTA curves for hydrated paste $\mathrm{C}_{4} \mathrm{~A}_{3} \hat{\mathrm{S}}$

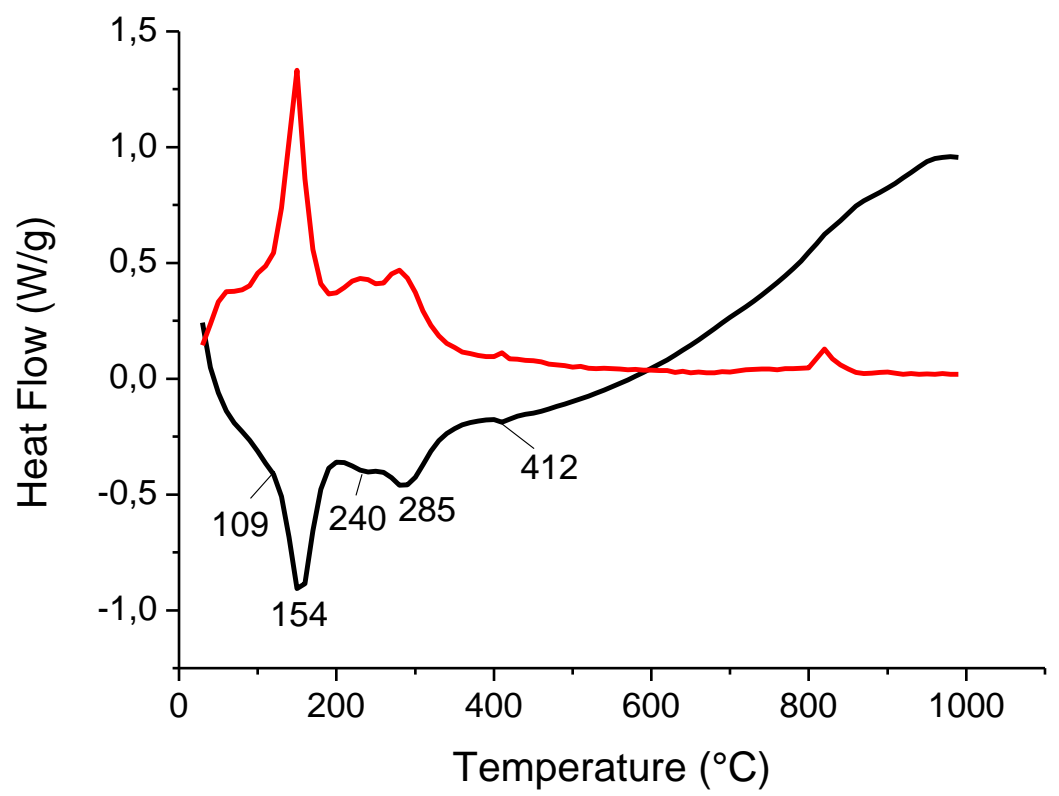

780 


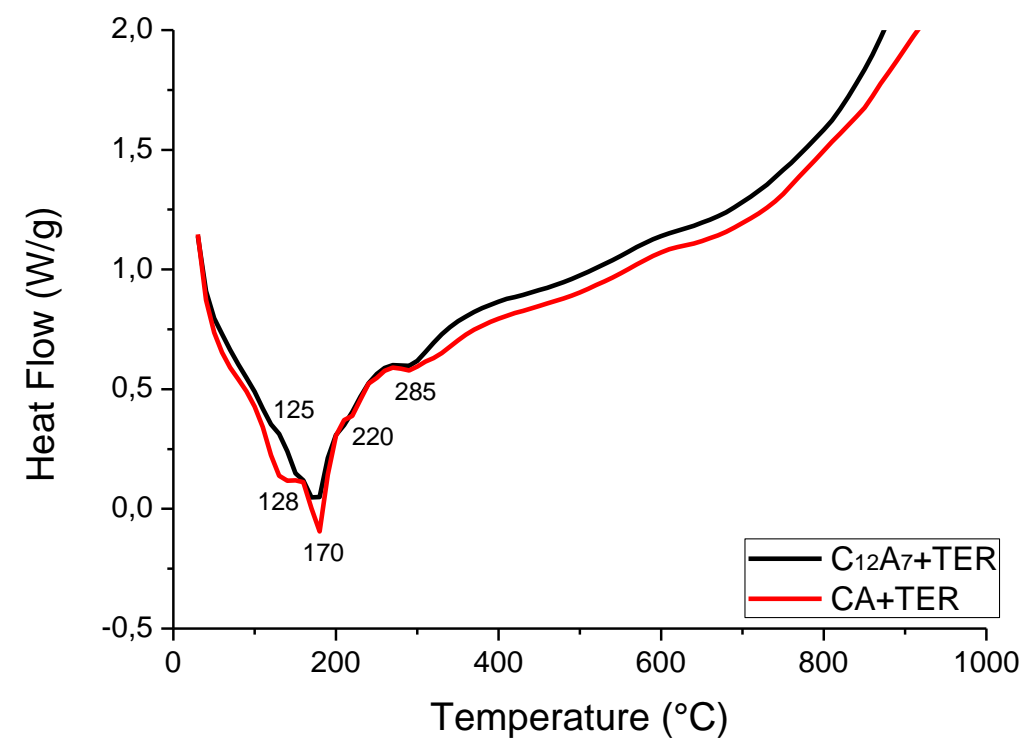

781

Figure 18.DTA curves for pastes $\mathrm{CA}+$ ternesite and $\mathrm{C}_{12} \mathrm{~A}_{7}+$ ternesite

783

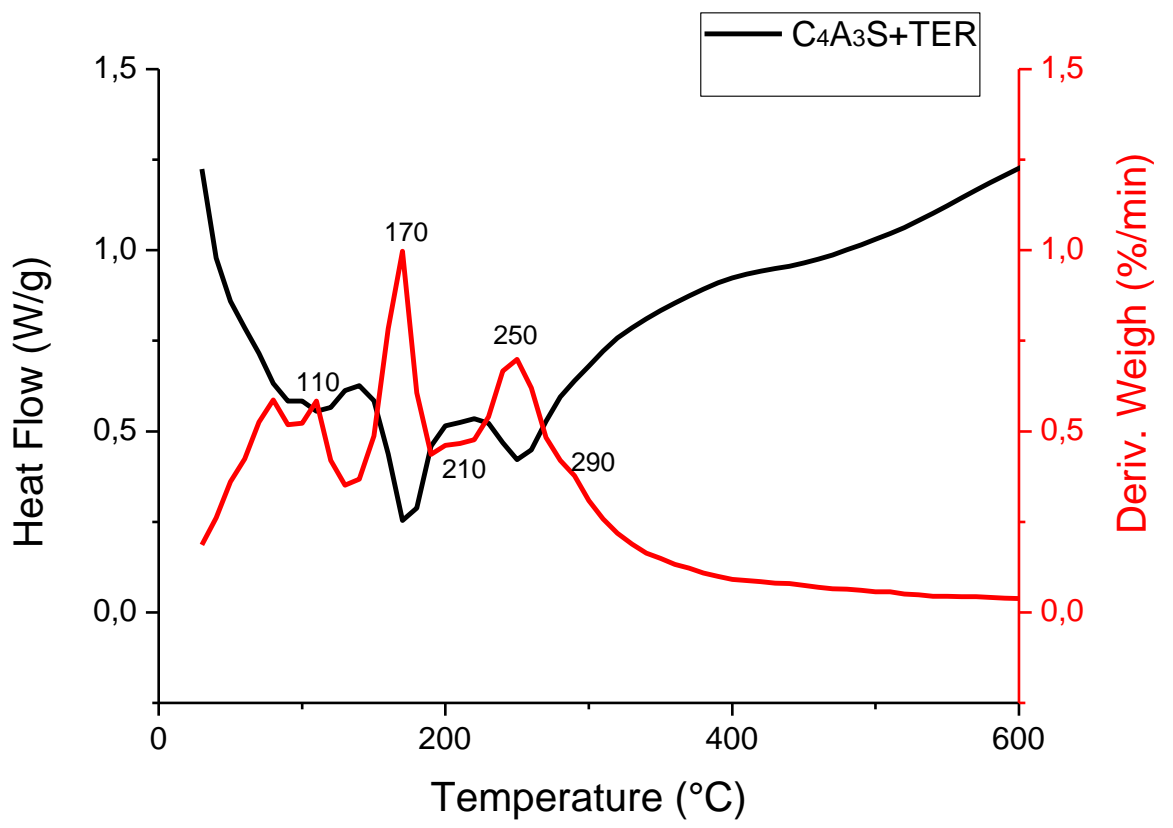

784

785

Figure 19.DTA curves for paste $\mathrm{C}_{4} \mathrm{~A}_{3} \overline{\mathrm{S}}+$ ternesite

786

787 